\title{
A POLISSEMIA DO ITEM LEXICAL 'LUZ’, UMA ANÁLISE BASEADA NA LINGUÍSTICA COGNITIVA
}

\section{ARTIGO ORIGINAL}

MALDONADO, Gabriel Orlando Quiñones ${ }^{1}$

MALDONADO, Gabriel Orlando Quiñones. A polissemia do item lexical 'luz', uma análise baseada na linguística cognitiva. Revista Científica Multidisciplinar Núcleo do Conhecimento. Ano. 07, Ed. 02, Vol. 04, pp. 117-163. Fevereiro de 2022. ISSN: 2448-0959, Link de acesso: https://www.nucleodoconhecimento.com.br/letras/linguistica-cognitiva

\section{RESUMO}

O presente artigo é uma abordagem das questões relacionadas à subárea da Linguística Cognitiva. Nesta investigação, tem como propósito analisar a polissemia do item lexical 'luz' em várias fontes lexicográficas. Portanto, também procurar-se-á um corpus linguístico para apresentar como o item 'luz' está presente na linguagemem-uso na experiência pessoal, social ou histórica. Desenvolveu-se o trabalho com base na seguinte questão norteadora: quais são os diferentes sentidos que 0 item polissêmico 'luz' tem em um mesmo protótipo? O presente estudo de investigação tem por objetivo: Baseado no corpus lexicográfico, analisar e discutir os sentidos múltiplos

\footnotetext{
1 Pós-doutorado em Divulgação da Ciência pela Universidade Virtual de Formación Internacional no México (2021); Diploma de Estudos Avançados em Linguística Portuguesa pela Universidade Aberta de Lisboa, Portugal (2021); Pós-doutorado em Educação com linha de pesquisa em Sociolinguística Musical Brasileira pela Universidade Virtual de Estudos Superiores - UNIVES no México (2020); Doutor em Ensino da Língua Portuguesa pela Bircham Internacional University em Madrid Espanha (2018); Mestre em Línguas, Culturas e Sociedades em Ambientes Multilíngues - Francês Língua Estrangeira pela "Université des Antilles" em Martinica (M1-2016 / M2-2018); Pós-graduado (Especialização) em Estudos de Língua Portuguesa: Investigação e Ensino pela Universidade Aberta de Portugal (2014): Graduado em Línguas Modernas, habilitação em Português/Francês, pela Universidad de Puerto Rico - Río Pedras (2009).
}

RC: 106976

Disponível em: https://www.nucleodoconhecimento.com.br/letras/linguistica-cognitiva 
do item polissêmico 'luz'. Foi utilizada a teoria dos protótipos para determinar os diferentes sentidos que tem o item 'luz' em um mesmo protótipo. Procurou-se as ocorrências do item polissêmico 'luz' no corpus linguístico especializado. Investigouse o uso do item 'luz' nas letras de samba-enredo da mesma Escola de Samba nas últimas 4 décadas (1980-2020). Buscou-se, também, identificar os diferentes sentidos que o item polissêmico 'luz' tem em um mesmo protótipo, as ocorrências que apresentam $\mathrm{o}$ item polissêmico 'luz' nas plataformas de CETEMPúblico e as ocorrências do item 'luz' no corpus de letras de sambas-enredo da Escola de Samba Beija-Flor de Nilópolis entre 1980 e 2020. Os principais resultados e conclusões foram que os dicionários apresentaram uma variedade de verbetes, mostrando assim o alto nível polissêmico da palavra 'luz'. Além disso, as ocorrências do item 'luz' no CETEMPúblico foram de 16 142, demonstrando a frequência do seu uso neste meio discursivo. Por último, nas letras de samba-enredo, foi evidente uma alta frequência do uso metafórico da palavra 'luz'.

Palavras-chave: Linguística, Cognição, Polissemia, Luz, Samba Enredo.

\section{INTRODUÇÃO}

A Linguística Cognitiva (doravante LC) apresenta-se como um paradigma teórico, o que nos permite explicar os fenômenos da linguagem de forma abrangente e não apenas considera os aspectos formais tradicionalmente estudados no estruturalismo ou na teoria gerativa. Em Silva (2006), destaca-se que os grandes dicionários oferecem todos os sentidos de uma palavra organizada em protótipos, incluindo os usos menos frequentes ou mais especializados. A LC também considera a linguagem como uma capacidade individualizada. Isso significa que deve estar relacionada aos aspectos da neurolinguística, psicolinguística, sociolinguística e da antropologia, permitindo que a linguagem funcione como uma ferramenta do conhecimento, da representação, da comunicação e da interação entre os indivíduos. Portanto, é muito importante esclarecer que a LC requer uma visão multidisciplinar da linguagem, o que permite novas perspectivas de análise e investigações. 
De acordo com Silva (1997), Batoréo (2004a) e Abrantes (2001a), a Linguística Cognitiva surgiu no final dos anos 1970 e início dos anos 1980, por um lado, devido ao interesse pelo fenômeno do significado, e, por outro lado, devido ao estudo psicolinguístico de Eleanor Rosch (ROSCH, 1978; ROSCH e MERVIS, 1975) sobre o papel importante da representação dos protótipos no processo de categorização. Silva (1997) apresenta a Linguística Cognitiva como o estudo da linguagem e como o veículo primordial do conhecimento na conexão com a experiência pessoal do mundo. As unidades e estruturas da linguagem não são analisadas como unidades independentes, mas como amostras das capacidades cognitivas gerais, da organização conceitual, dos princípios de categorização, dos mecanismos de processamento e da experiência cultural, social para cada indivíduo. Batoréo (2004a), explica que a linguística cognitiva amplia os fundamentos da pesquisa em linguagem, muito além do escopo estabelecido pela linguística tradicional, em busca de outras fontes de explicação científica, como a psicologia, a filosofia ou a etnologia. Segundo esta autora, de acordo com os cientistas cognitivos, não existem categorias conceituais estritas e nem limites definidos (BATORÉO, 2004a).

Desenvolveu-se o trabalho com base na seguinte questão norteadora: quais são os diferentes sentidos que o item polissêmico 'luz' tem em um mesmo protótipo? O presente estudo de investigação tem por objetivo: Baseado no corpus lexicográfico, analisar e discutir os sentidos múltiplos do item polissêmico 'luz'. Buscou-se, também, identificar os diferentes sentidos que o item polissêmico 'luz' tem em um mesmo protótipo, as ocorrências que apresentam o item polissêmico 'luz' nas plataformas de CETEMPúblico e as ocorrências do item 'luz' no corpus de letras de sambas-enredo da Escola de Samba Beija-Flor de Nilópolis entre 1980 e 2020.

\section{ENQUADRAMENTO TEÓRICO}

Silva (2006) expõe que o estudo da polissemia não é apenas um fenômeno de mudanças linguísticas, mas também da linguagem-em-uso, da aquisição de linguagem e do seu progresso, do pensamento e da sociedade. Segundo Silva, Bréal (1924) acredita que a polissemia é uma das melhores respostas às necessidades 
cognitivas e sociais do falante. Também no uso e na psicologia do locutor, na relação com a cognição e nos aspectos culturais que devem ser estudados. Além disso, Bréal (1924) não apenas criou termos adequados para o conceito de nomes inadequados, mas também lançou uma base teórica para o estudo da polissemia como acontecimentos da linguagem, da cognição e da cultura. A área da LC usa a teoria dos protótipos para determinar os diferentes sentidos que tem uma unidade lexical. Isso mostra a argumentação de sentidos em volta do centro (protótipo) ou a falta de limites bem definidos. Essas extensões de significados estão vinculadas à linguagem em uso pelas diferentes comunidades linguísticas. Silva (2006) esclarece que a polissemia é um fenômeno de categorização de protótipos, ou seja, é baseada em protótipos e não em "condições necessárias e suficientes"; o que significa que os vários usos do objeto são organizados em torno do centro do protótipo e por semelhanças familiares entre si. Mais explicitamente, a estrutura do complexo polissêmico é moldada por vários efeitos de prototipicidade (GEERAERTS, 1989), isto é apresentado com os diferentes graus de representatividade entre os sentidos, organizando os sentidos de acordo com semelhanças e sobreposições familiares, sem limites precisos entre eles. Segundo Silva (2006, p. 13):

A dimensão qualitativa da polissemia compreende os vários sentidos que uma palavra pode ter e as diferentes relações que podem unir esses sentidos, designadamente a metáfora, a metonímia, a generalização e a especialização de sentido. Saber que sentidos tem uma palavra e como é que eles estão semanticamente relacionados são, pois, as grandes questões qualitativas da polissemia.

Os estudos polissêmicos baseiam-se no fenômeno diacrônico e estes são bem acolhidos no enquadramento teórico da linguística cognitiva. O conceito de polissemia ilustra a transformação de esquemas de imagens, modelos metafóricos e metonímicos. Silva (2006) expõe que o estudo da polissemia não é apenas um fenômeno de mudanças linguísticas, mas também da linguagem em uso, da aquisição de linguagem e do seu progresso, do pensamento e da sociedade. Segundo Silva (2006), Bréal acredita que a polissemia é uma das melhores respostas às necessidades cognitivas e sociais do falante. Também no uso e na psicologia do locutor, na relação com a cognição e nos aspectos culturais que devem ser estudados. 
Além disso, Bréal não apenas criou termos adequados para o conceito de nomes inadequados, mas também lançou uma base teórica para o estudo da polissemia como acontecimentos da linguagem, da cognição e da cultura. Silva (2006), explica que o modelo de rede esquemática tem duas categorizações, por esquema e por protótipos. $\mathrm{O}$ esquema abstrai o que é comum à sua instância. $\mathrm{O}$ que significa que a instância adquiriu as especificações do esquema, mas as expande com mais detalhes nessa rede de sentidos. Segundo Silva (2006) a sedução da linguística cognitiva pela polissemia, a sua tendência à análise polissêmica em termos de redes esquemáticas e redes radiais, foram popularizadas por Langacker (1987) e Lakoff (1987), com a tendência de postular representações mentais idênticas.

\section{METODOLOGIA}

Inicia-se a investigação com a recolha do corpus lexicográfico dos dicionários impressos Houaiss (2009) e Aurélio (2010) e do dicionário online Michaelis (2015). Em segundo lugar, continuamos com o levantamento do corpus linguístico na plataforma de Linguateca e na página web de 'letras.com'. Todos os dados coletados serão organizados e colocados na parte dos anexos. Depois, analisar-se-á e comparar-seá o item luz baseados nos três dicionários acima mencionados. Em seguida, se procederá com a análise e a comparação do corpus escolhido na Linguateca e nas letras de samba-enredo. Decidiu-se limitar esta parte só à Escola de Samba de BeijaFlor de Nilópolis, já que no Brasil existem muitíssimas escolas e só precisamos analisar a existência das ocorrências do item 'luz' nas letras dos sambas dessa escola. Para finalizar, faremos várias propostas de rede de sentidos para o item em estudo e serão colocadas nos anexos. 


\section{RESULTADOS, DESCRIÇÃO E ANÁLISE}

\subsection{APRESENTAÇÃO, DESCRIÇÃO E ANÁLISE DO CORPUS DOS DADOS LEXICOGRÁFICOS}

Na primeira análise, ambicionamos identificar os diferentes sentidos polissêmico do item 'luz'. Portanto, nesta análise inicial apresenta-se o corpus lexicográfico estabelecido pelos dados coletados nos dicionários Houaiss (2009), Aurélio (2010) e Michaelis (2015). A consulta aos dicionários permite-nos identificar que a palavra de investigação possui um elevado nível de polissemia. Posteriormente usaremos os mecanismos cognitivos de especificação, generalização, metáfora e metonímia para pormenorizar a polissemia do item 'luz'. No Houaiss (2009), encontramos uma datação de 1041 para o substantivo 'luz', ao contrário dos outros dois dicionários em que a informação não está disponível. A etimologia do lexema 'luz' está referenciada como originaria do latim: $L \bar{u} x$, lūcis: 'luz, claridade, iluminação, dia'. Por tanto, a 'luz' está vinculada com a 'claridade' a 'iluminação' e com o 'dia'.

Nos dicionários, o significado que corresponde à primeira entrada dos verbetes, define o item lexical 'luz' no Aurélio (2010) como "radiação eletromagnética capaz de provocar sensação visual num observador normal" e no Michaelis (2015) como "porção da irradiação eletromagnética à qual os órgãos da visão reagem". No dicionário Houaiss (2009), encontrou-se que o verbete inicial difere com os primeiros dois acima mencionados. Houaiss (2009) define 'luz' como "capacidade de visão" e concorda com a primeira definição do Aurélio (2010) e do Michaelis (2015) no verbete número vinte. Então, identificamos o sentido prototípico como "Radiação eletromagnética capaz de provocar sensação visual num observador normal". A partir do protótipo, encontramos várias expressões que podem ser classificadas no sentido de generalização, como em: 'luz natural', 'luz refletida', 'luz dos corpos celestes', 'luz artificial', e 'fontes de luz'. A palavra 'luz' pode ser encontrada em várias expressões que apresentam um processo de especificação: 'luz do sol' e 'luz do dia' que na Astronomia é identificada como a iluminação que procede do sol. Na especificação, também estão presentes as expressões como 'luz das estrelas', 'luz da lua', fazendo 
referência à claridade que difundem os corpos celestes, própria ou refletida. No caso da 'luz da lua', é a luz refletida do sol. Em adição, temos outras expressões com esse sentido de especificidade: 'A luz da fogueira' 'A luz da lâmpada' aqui encontramos a interpretação de claridade produzida por coisas diversas como: fogueira, lâmpada, entre outras.

Igualmente, a eletricidade é um fenômeno natural que pode gerar 'luz', pois, contém muitos elétrons. Este fenômeno está presente em tempestades, furacões e entre outros eventos atmosféricos, quando ocorre um impacto entre os diferentes componentes eletromagnéticos. Devido a essa situação, é liberada uma radiação eletromagnética chamada de relâmpago ou raio. Isso, gera iluminação e claridade diante da visão do ser humano. A eletrificação também pode surgir quando dotamos cidades, casas, etc., para ser capazes de gerar 'luz'. Então, classificamos esse outro fenômeno como 'energia elétrica' ou 'luz elétrica' e ela fornece-nos a "claridade", a 'iluminação' ou a 'energia' necessária para os diferentes eletrodomésticos e para o período noturno quando estamos carentes de 'luz solar'/ 'luz do dia'. Nos dicionários, não se encontraram essas expressões de 'energia elétrica' nem 'luz elétrica' como parte dos verbetes ou locuções. Algumas locuções metafóricas com o item 'luz' são as seguintes: (i) Na astronomia, a 'luz antissolar', (ii) na fotografia, a 'luz artificial', (iii) na óptica, a 'luz branca', (iv) na fotografia ou no teatro, a 'luz de fundo', (v) a aeronáutica ou em náutica, a 'luz de navegação', (vi) na astronomia, a 'luz natural', (vii) na óptica, a 'a luz refletida', (viii) na astronomia, a 'luz terrestre'.

Silva (2006) esclarece que identificar a existência de uma relação entre diferentes significados relacionados a uma mesma forma de linguagem é o critério para determinar a distinção entre os termos teóricos da polissemia e da homonímia. Em primeiro lugar, o item lexical 'luz' é grafado em uma só palavra e é um substantivo comum no singular feminino. Nos dicionários Aurélio (2010) e Michaelis (2015) não introduz nos seus verbetes alguma palavra que permita a distinção do fenômeno de homonímia para o item 'luz'. Por outro lado, Houaiss (2009) nos identifica que o item 'luz' é homônimo na flexão do verbo 'luzir'. Isso significa que o verbo 'luzir'[2] conjugado no presente do indicativo da $3^{\text {a }}$ pessoa do singular seria 'Você luz', nesse 
caso homógrafo com o substantivo feminino 'luz' no singular. Também incorpora o plural 'luzes' como um homógrafo do mesmo verbo no presente do indicativo da $2^{\mathrm{a}}$ pessoa do singular, 'tu luzes'. Em segundo lugar, encontramos outra entrada homonímica com o item composto por 'luz-do-dia'. Esse item composto não tem nada a ver com o nosso item 'luz'. A 'luz-do-dia' é escrita com hifens, porque está classificada na área de botânica como um espécime das angiospermas, LABLABE. Os dicionários apresentam-nos consenso em duas entradas metonímicas. Essas derivações por metonímia são: (i) objeto próprio para iluminar, exemplo: a luz do quarto queimou, (ii) fonte de luz usada como sinal para a navegação, trânsito, etc.; farol, semáforo. Também deparamos com a palavra 'luzeiro', [luz + -eiro (sufixo derivacional)] que é usada para identificar todo animal, coisa ou corpo celeste que irradia luz. Por extensão metonímica, os dicionários Michaelis (2015) e Aurélio (2010) incorporam a palavra (iii) 'dinheiro' como sinônimo de 'luz'. No Aurélio (2010) é identificada essa entrada como uma gíria dos ladrões no Brasil, especificamente do Rio de Janeiro.

Por outra parte, os corpora lexicográficos evidenciam uma maior extensão para o lexema 'luz' nos verbetes de sentido metafórico, como já foi mostrado. Além disso, existem outras derivações por extensão metafórica. Elas são encontradas quando expomos o nosso (i) [ponto de vista], por exemplo, 'analisaram os fatos sob uma luz desfavorável', em uma (ii) [ideia] que ilumina a mente; esclarecimento, elucidação, informação como, por exemplo, 'Ela lançou uma nova luz sobre a questão'. Também em (iii) caráter de clareza, de evidência, de certeza, que alguma coisa oferece ao espírito expresso na frase 'nada trará luz para esse impasse'. Em (iv) [percepção/ intuição/ erudito] é referenciada como uma faculdade de perceber as coisas; inteligência, e baseados nela encontramos a seguinte expressão: 'Adoro conversar com ele, pois é um homem de muitas luzes'. No âmbito do (v) [conhecimento público] podemos exemplificar com a seguinte frase, 'a imprensa trouxe à luz fatos escabrosos'. Ainda mais, na classificação de (vi) [brilho, fulgor] encontramos a expressão metafórica, 'vi em seus olhos a luz da cobiça'. Uma (vii) [pessoa] que traz clareza, iluminação mental ou espiritual e com basto intelecto, poderia designar-se ser 
'um homem de luz'. Igualmente, o uso metafórico do item 'luz' na categoria da (viii) [religião]. Na religião é a iluminação espiritual como atributo divino ou a incorporação da verdade divina; verdade suprema (a doutrina cristã); a fé. Enfim, nela encontramos a expressão a seguir: 'A ação divina explica-se no mundo pelo caminho da luz'. Concluímos esta parte do estudo explicando que o item 'luz' está presente em outras expressões metafóricas como: 'à luz da ciência', com o sentido de 'normas ou princípios'. 'Dar uma luz' como alternativa, ideia ou saída de um problema. Também 'lançar luz sobre' um assunto, em que essa expressão é usada quando é trazida alguma informação relevante para dúvidas ou questões. 'Dar à luz'; parir (um filho)., 'Vir à luz' usada no sentido de vir ao mundo; nascer ou tornar-se conhecido, por exemplo, o dicionário Houaiss (2009) incorpora a expressão 'Os Lusíadas vieram à luz em 1572'.

Imagem 1: Rede de sentidos da palavra luz no dicionario

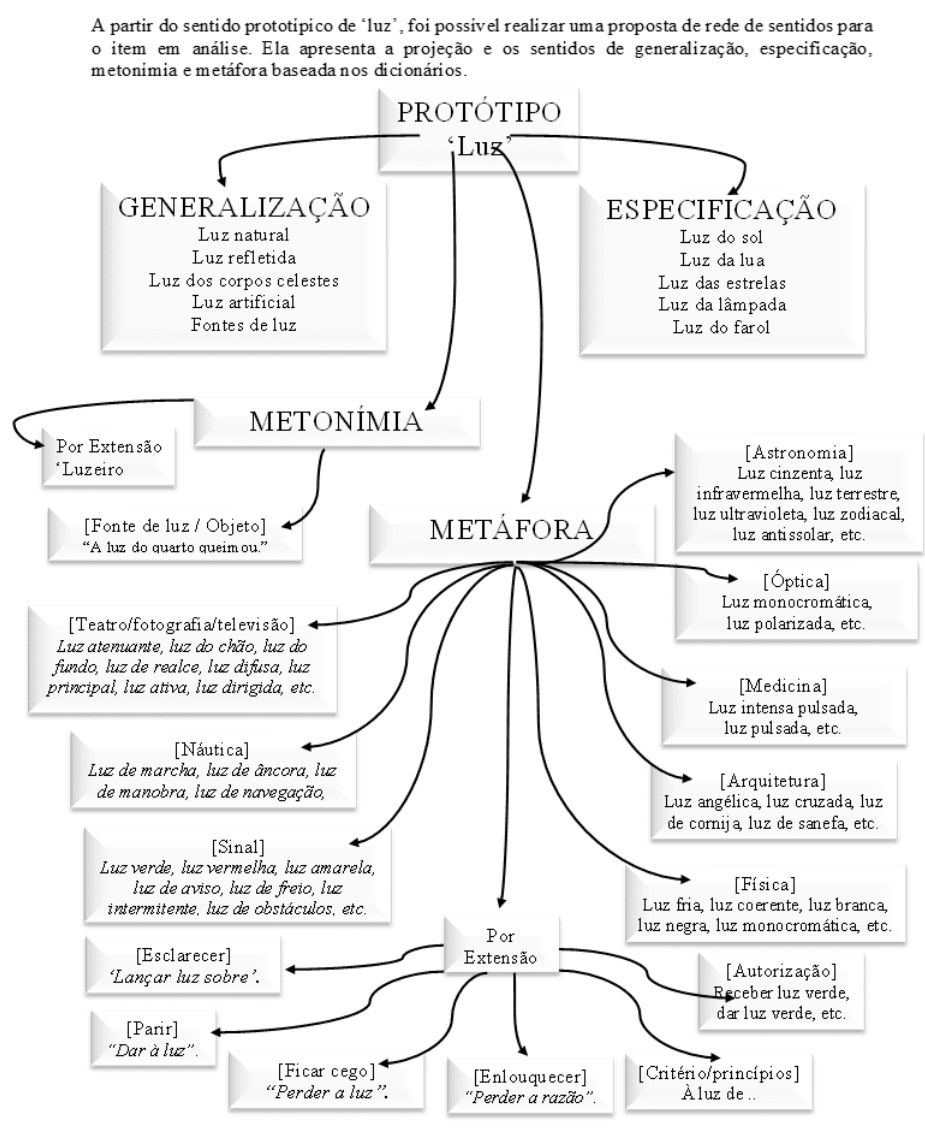

Fonte: Elaborado pelo autor (2022)

RC: 106976

Disponível em: https://www.nucleodoconhecimento.com.br/letras/linguistica-cognitiva 


\subsection{ANÁLISE DO CORPUS ELETRÔNICOS DE LINGUATECA}

Consulto-se o site da Linguateca, especificamente CETEMPúblico, no dia 26 de janeiro de 2021. Por meio do mecanismo de busca do sítio, o sistema nos proporcionou 16142 ocorrências, das quais, só 8000 se encontravam acessíveis na página dos resultados. Para analisar a representação do item 'luz' em ocorrências de discursos escritos, selecionamos os primeiros cem excertos do corpus linguístico na plataforma. Escolhemos essa quantidade por questões de limite do nosso trabalho. Essa pequena amostra constitui uma manifestação aleatória da base de dados eletrônica, já que nela poderia ser evidenciada a linguagem-em-uso do nosso lexema. $\mathrm{Na}$ amostra de 100 excertos, o item 'luz' mantêm seu o sentido protótipo em 3\% das ocorrências. Quando a palavra "luz" é usada para se referir a "Radiação eletromagnética capaz de provocar sensação visual num observador normal", estamos no núcleo prototípico ou perto dele, como em: 'quando vi luz' (= perceber a luz, ver uma luz), 'ausência de luz' e 'falta de luz' (= carecer da luz, não perceber a luz ou não ver a luz). Nas ocorrências selecionadas, procuramos possíveis casos de homonímia com base nos critérios etimológicos apresentados nos três dicionários usados nesta pesquisa. De acordo com os fragmentos de CETEMPúblico, encontramos o item 'luz' com 1\% de ocorrência homónima. Nesse caso, 'luz' é a conjugação do verbo 'luzir' na terceira pessoa do singular, no presente do indicativo.

$\mathrm{Na}$ linguagem-em-uso coletada, o sentido de generalização foi encontrado em $6 \%$ das expressões: 'fonte de luz', 'meios tecnológicos de luz', e 'a luz natural'. Essas expressões referem-se ao reagrupamento no tipo de luz a ser emitida, como fonte de emissão, seja ela natural ou artificial e qualquer outro termo de generalização. As fontes de luz podem ser classificadas como: naturais, refletidas ou artificiais. As fontes naturais criam a luz que emitem, outras refletem a luz de diferentes fontes; por exemplo, 'a luz da lua' não é produzida de forma natural por ela, mas é o reflexo da 'luz do sol'. Em relação às fontes de luz, em geral, pode-se fazer uma distinção entre naturais como 'a luz do sol' e as artificiais com 'a luz da lâmpada'. Porquanto, esse é o sentido de especificação, presente em $20 \%$ da amostra. As especificações são evidenciadas quando tomamos em consideração o que produz a 'luz'. Os excertos de 
CETEMPúblico, nos proporcionou as seguintes expressões de especificação: 'a luz doméstica', 'luz do computador', 'luz dos holofotes', 'luz solar', 'luz do dia', 'a luz da cidade de Lisboa', 'a luz de Lisboa', 'à luz de centena de velas', 'à luz da manhã', 'a luz prateada e difusa da lua cheia', 'um feixe de luz azul', 'a luz da estrela', 'a luz elétrica', 'da luz ambiente'.

A amostra usada para a análise da linguagem-em-uso proporcionou-nos em $7 \%$ das ocorrências, o sentido metonímico. Nesse sentido temos expressões como: 'acender a luz', 'corte de luz', 'com luz acesa', 'inauguração da luz elétrica'. Nessas duas representações marcamos a substituição do objeto "lâmpada" que é o condutor da radiação eletromagnética artificial, em que mudamos o seu nome para o efeito que produz, que é a 'luz'. Também temos o efeito de personificação ou instanciação, como em: 'aldeia da luz', 'anjo da luz', 'Nossa Senhora da Luz'.

O sentido metafórico abrange $63 \%$ do corpus linguístico e neste estudo é a percentagem que compreende a maior quantidade de ocorrências. Em primeiro lugar, dentro dessa percentualidade, encontramos $11 \%$ que exemplificam o frequente uso da expressão metafórica 'luz verde'. As cores usadas nos semáforos são três: uma luz vermelha para parar, uma luz amarela para desacelerar e uma luz verde para continuar o nosso percurso. O que significa que também temos uma especificação para a expressão 'luz verde', quando é utilizada para identificar as mudanças de sinais (avisos) nas cores do semáforo. Enfim, deparamos com as seguintes expressões metafóricas: na [Autorização] 'luz verde', na [Religião] 'a luz do Rosto de Deus', 'a luz divina', 'a luz do Espírito Santo', nos [Critérios / princípios] 'à luz de', [Parir] 'dar à luz', em [Medição / alcance] 'medir a luz', 'ampliar a força da luz', nas [Emoções] 'ser a luz dos olhos do próprio pai', e na [Esperança] 'ver luz ao fundo do túnel'. 
Imagem 2: Rede de sentidos de luz na linguagem em uso

\begin{abstract}
A partir do sentido prototipico de 'luz', foi possivel realizar uma segunda proposta de rede de sentidos para o item em análise. Ela apresenta a projeção e os sentidos de generalização, especificação, metonimia e metáfora na linguagem em uso.
\end{abstract}

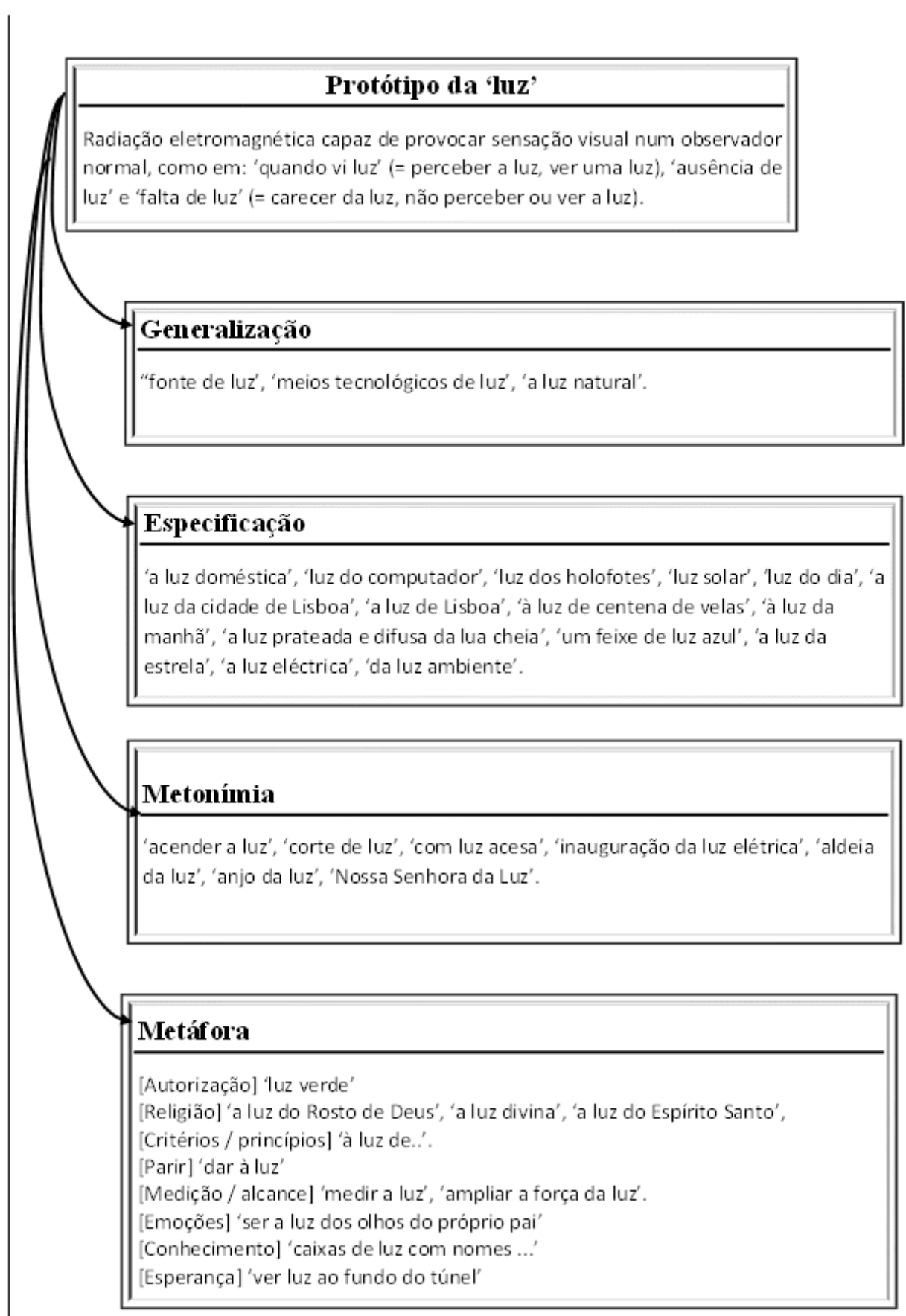

Fonte: Elaborado pelo autor (2022) adaptada a partir de Batoréo (2011)

RC: 106976

Disponível em: https://www.nucleodoconhecimento.com.br/letras/linguistica-cognitiva 


\subsection{ANÁLISE DO CORPUS ELETRÔNICO DO NOME ‘LUZ’.}

Para analisar a representação do nome 'Luz' em ocorrências de discursos escritos, consultamos novamente a plataforma eletrônica de CETEMPúblico, no dia 30 de janeiro de 2021. Por meio do mecanismo de busca do sítio, o sistema mostrou o resultado de 10687 ocorrências, das quais, só 8000 estavam disponíveis. Selecionamos os primeiros cinquenta excertos do corpus linguístico da plataforma. $\mathrm{Na}$ amostra de 50 excertos, o nome 'Luz' tem uma representação diversa, correspondentes ao sentido metonímico. Lembremos que o item "luz" é a "Radiação eletromagnética capaz de provocar sensação visual num observador normal". Portanto, iniciamos no nível concreto, já que o sentido da visão nos permite perceber, ver e concretizar a 'luz'.

Poder-se-ia dizer que a polissemia de 'luz' está presente desde os inícios da religião. Segundo a Bíblia, Deus disse que "Haja luz". Portanto, há uma variedade de expressões que representam o sentido metafórico de 'luz' na religião. Do sentido prototípico de luz ancorado ao nível concreto, passamos ao nível abstrato. A palavra luz representa e simboliza muitas coisas importantes na Igreja Católica, entre elas, encontramos a imagem da Nossa Senhora da Luz. As origens religiosas podem ser diversas, alguns explicam que surge na Itália e outros nas Ilhas Canárias, mas o nosso estudo não se baseia nessas peculiaridades. O que corresponde dizer é que estamos no nível abstrato da personificação de "Nossa Senhora da Luz". Em seguida, passa por uma transformação de especificação com o nome próprio 'Maria da Luz', que no final se torna uma forma curta e familiar com o nome 'Luz'. Assim, mudamos novamente do nível abstrato para o nível concreto. Nesse nível concreto, encontramos vários usos do nome familiar 'luz' implementados em coisas que existem e são materializadas na realidade.

Em primeiro lugar encontramos a instanciação com o nome próprio do templo religioso, 'Igreja de Nossa Senhora da Luz' ou 'Igreja da Luz', constituindo está uma especificação metonímica. Em segundo lugar, temos o nome ou sobrenome 'Luz', como em: 'Luz Rodrigues' e 'Silvino da Luz'. Terceiro, encontramos uma variedade de 
edifícios arquitetônicos, mostrando o sentido de especificação metonímica, como em: 'Fortaleza da Luz', 'Estádio da Luz', 'Pavilhão da Luz' e 'Farol da Luz'. Notamos também uma entrada de generalização metonímica com as 'Bancadas da Luz' pertencentes ao referido estádio. Noutro fragmento, evidencia-se a celebração religiosa da 'Nossa Senhora da Luz' com a 'Feria da Luz'. Concluindo esta análise, temos várias ocorrências em termos de localização. Encontramos duas generalizações metonímicas com 'Luz, Lagos' e 'Bairro da Luz', além de duas ocorrências por especificação metonímica com 'Praia da Luz' e 'Serra da Luz '. Nos anexos, estará disponível a representação de uma rede de sentidos para os oito traços metonímicos do caso polissémico do nome 'Luz'. 
Imagem 3: Representação da rede basica das metononimias fundamentais entrelaçadas no caso de polissemiada da palavra Luz

A partir do sentido prototípico de 'luz', foi possivel realizar uma terceira proposta de rede básica das metonímias fundamentais para o item em análise. Ela apresenta a projeção e os sentidos concretos e abstratos na linguagem em uso

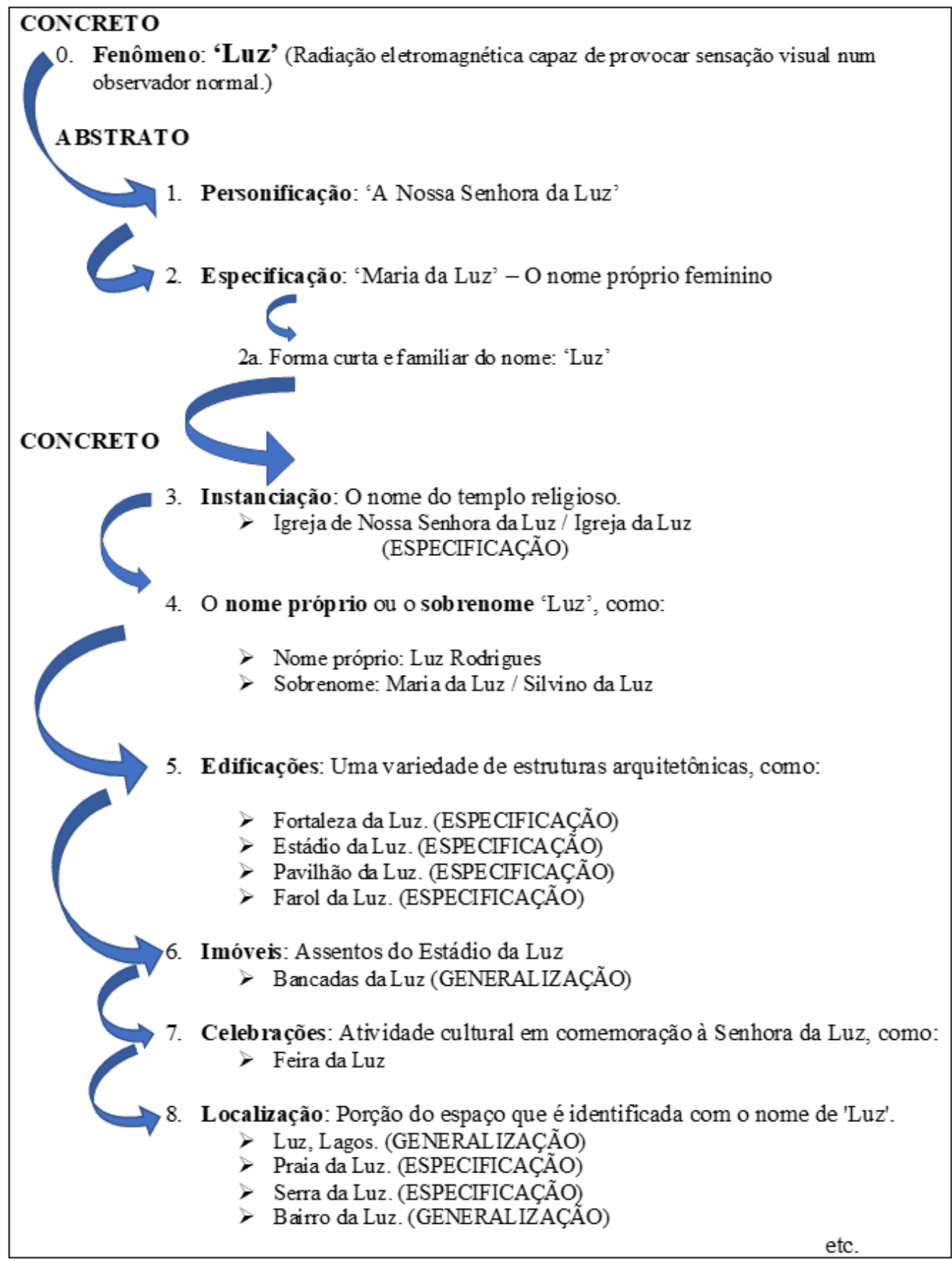

Fonte: Elaborado pelo autor (2022) adaptada a partir de batoréo (2017) 


\subsection{INFORMAÇÃO SOBRE A ESCOLA DE SAMBA BEIJA-FLOR DE NILÓPOLIS.}

Apresentamos um resumo dos inícios da Escola de Samba Beija-Flor de Nilópolis do Rio de Janeiro e a definição do que é o samba-enredo. Segundo Musa e Simas (2010), esta escola começou em 1948 como um bloco carnavalesco. Posteriormente, em 1953, tornou-se oficialmente uma escola de samba. Beija-Flor é atualmente a única escola de samba conhecida por ter um estilo de composição próprio, que materializa plenamente a resistência do estilo samba-enredo. De acordo com Lopes e Simas (2020), A escola de samba é uma sociedade de música e entretenimento que participa dos desfiles de carnaval. Esses autores afirmam que o samba é composto por letra e melodia, as quais são elaboradas a partir da síntese temática do enredo escolhido pela própria agremiação (LOPES e SIMAS, 2020).

Segundo Scorsolini-Comin; Pacífico e Romão (2011, p. 123):

Tudo é uma trama, um jogo, uma produção de sentidos que não se finda com a passagem da escola pela avenida, tampouco com a escolha de um significante e não de outro. Com a finalização do desfile, não se instaura a resolução dos segredos e das expectativas criadas em torno do enredo "É segredo!", mas continua o movimento de produção de sentidos, solicitando ao espectador um exercício no sentido de compreender as polissemias em desfile e em discursos.

\subsection{ANÁLISE DO CORPUS DE LETRAS DE SAMBA-ENREDO.}

Analisou-se um corpus de letras de samba-enredo, coletado na plataforma de letras.com. Nesta parte, as letras procuradas e analisadas foram delimitadas a uma escola de samba e às últimas quatro décadas. A Beija-Flor de Nilópolis, foi a escola de samba selecionada para analisar as ocorrências do item 'luz' nas suas letras de samba-enredo. As escolas de samba, em geral, têm a missão de criar uma letra de samba-enredo para cada ano e apresentá-la no carnaval. Decidimos investigar as letras registadas na plataforma de letras.com nas últimas quatro décadas. Analisamos 40 letras de samba-enredo correspondente aos anos de 1980 a 2020. O resultado foi que encontramos 17 letras com o nosso item polissêmico 'luz' como parte do seu 
enredo. Então, esta amostra representa 43\% da linguagem-em-uso de 'luz', nesse tipo de discurso escrito. Em adição, expomos que cada letra de samba-enredo é cantada e tem um alcance maior do que um texto escrito. Assim, com a sua temática cantada durante o ano todo e a difusão nas emissoras de rádio, além do carnaval, influenciam na Linguagem, Cognição e Cultura, tanto para os brasileiros como para os estrangeiros.[3]

A análise permitiu-nos identificar a polissemia de 'luz' em pelo menos um trecho de cada uma dessas dezessete letras de samba-enredo. As ocorrências de letras de samba-enredo apresentam três mecanismos cognitivos. O sentido prototípico de 'luz' está representado em 1 ocorrência com o significado de 'toda radiação eletromagnética' apresentado nos dicionários[4]. A seguir mostramos o fragmento que marca o uso prototípico de 'luz' em duas das dezessete letras de samba-enredo analisadas. Nesse exemplo, temos a única ocorrência de 'luz' nas letras de sambaenredo da década de 1980, o fragmento é o seguinte: 'tudo é brilho, luz e cor (luz e cor)', aqui estamos perante do sentido prototípico e a letra data de 1987. No segundo exemplo, 'um templo sagrado a luz do luar' está presente a única ocorrência de sentido de especificação com 'a luz do luar'. A letra desse segundo exemplo está datada de 2016. As ocorrências metafóricas para o item 'luz' estão representadas em $88 \%$, o que corresponde a 15 das 17 letras analisadas. Os próximos fragmentos foram identificados com a data do ano da sua composição e registo, para evidenciar o percorrer de 'luz' nessas quatro décadas analisadas. Nos anos noventa, encontramos a letra de 1990 com 'a luz resplandeceu o caos', em 1992 'um ponto de luz surgiu, oi!', em 1993 'e vai bordando no chão um arco-íris de luz' e em 1995 com 'É festa, é luz, é cor, é poesia', nesta última aludindo a que a cantora de ópera Bidu Sayão é luz. Na próxima década, aumentou o uso polissêmico de 'luz'. A frequência do uso é representada com as letras a seguir: em 2000 com 'luz celestial que ilumina', seguimos com 2001 'na luz dos seus Voduns', também em 2003 com 'Luz, divina luz que me conduz', em adição em 2004 com 'A Amazônia é Brasil, é luz do criador'. Esses sentidos estão vinculados metaforicamente à religião. Para finalizar a década, em 2008 encontramos o excerto de 'A luz solar ilumina meu interior', mostrando como o 
sentido de especificação de 'luz solar' vira uma extensão metafórica complementandoa com 'iluminar meu interior'. A última década analisada foi a de 2010, na qual também encontramos um incremento nas ocorrências em relação à década anterior. Iniciamos os exemplos com a letra de 2010 com o fragmento 'a luz da alvorada anuncia!'. Depois em 2011, a letra de samba-enredo nos oferece o verso 'Eu cheio de fantasia na luz do Rei menino'. Em seguida, em 2012, o nosso item é apresentado como parte do sincretismo religioso em 'Na casa nagô a luz de Xangô Axé'. Anos depois, em 2017, incorpora a história da indígena Iracema e diz que ela é 'um raio de sol a luz do meu dia'. No seguinte ano, em 2018, a Escola de Samba interpretou a letra de crítica social ao governo com a esperança de ter uma melhor vida. Esse fragmento é o seguinte: 'à procura de uma luz, a salvação'. Enfim, em 2019, a letra narra as fábulas da própria escola e diz que ela é 'razão do meu cantar, a luz do meu viver, O que seria de mim sem você?'.

\subsection{DISTINÇÃO ENTRE HOMONÍMIA E POLISSEMIA}

Silva (2006) esclarece que identificar a existência de uma relação entre diferentes significados relacionados a uma mesma forma de linguagem é o critério para determinar a distinção entre os termos teóricos da polissemia e da homonímia. Em primeiro lugar, o item lexical 'luz' é grafado em uma só palavra e é um substantivo comum no singular feminino. Em segundo lugar, não encontramos evidência da existência de algum sintagma grafado que permita a distinção entre o item 'luz' e outro homógrafo. Inesperadamente, precatamo-nos que a palavra 'luz' é homófona com o nome 'Luiz', isto baseados no Português Brasileiro. O nome 'Luiz' é categorizado como um substantivo próprio. Na análise dos dois itens, observa-se o fenômeno da homonímia. Essa ocorrência está caracterizada ao usar a variação nacional do Brasil. Por conseguinte, estaríamos perante uma peculiaridade de sequência fônica semelhante. Para ser mais específico, neste caso está presente a homofonia, mesmo não tenhamos estudos cognitivos sobre o assunto. Vários autores brasileiros apresentam a existência da "ditongação da vogal tônica final seguida de /s/, resultando nas pronúncias: "pais" [paz]; "mêis" [mês]; "” [faz]; "arrôis" [arroz] e o nosso item em estudo; "luis" [luz]. Essa distinção está presente nos textos de Bagno (2007 e 2013), 
Castilho et al. (2019) e mais específico para o nosso trabalho, a pronúncia de 'luz' faz parte dos exemplos colocados em Martins (2016), Basso (2019) e Zampaulo (2019). Baseados nesses autores e na plataforma do Instituto de Linguística Teórica e Computacional, organizou-se uma tabela comparativa dos traços fonéticos do item 'luz' para fazer visível o fenômeno da homofonia.

Tabela 1. A tabela está baseada nos textos referenciais e na plataforma do Instituto de Linguística Teórica e Computacional (ILTEC) - Dicionário Fonético.

\begin{tabular}{|c|c|c|c|}
\hline $\begin{array}{l}\text { Pronúncia } \\
\text { indicativa para } \\
\text { a palavra luz } \\
\text { na região de } \\
\text { Lisboa. } \\
\text { (padrão) }\end{array}$ & $\begin{array}{l}\text { Pronúncia } \\
\text { indicativa para a } \\
\text { palavra luz na } \\
\text { região do Rio de } \\
\text { Janeiro, no } \\
\text { Brasil. (padrão) }\end{array}$ & $\begin{array}{l}\text { Pronúncia indicativa para } \\
\text { a palavra luz na variação } \\
\text { do Brasil. }\end{array}$ & $\begin{array}{l}\text { Pronúncia } \\
\text { indicativa para a } \\
\text { palavra (nome) } \\
\text { Luís ou Luiz na } \\
\text { região de Lisboa e } \\
\text { do Rio de Janeiro. } \\
\text { (padrão) }\end{array}$ \\
\hline $\begin{array}{l}\text { I'uJ } \\
\text { (ILTEC) } \\
\text { Dicionário } \\
\text { Fonético. }\end{array}$ & $\begin{array}{l}\text { I'uf } \\
\text { (ILTEC) } \\
\text { Dicionário } \\
\text { Fonético. }\end{array}$ & $\begin{array}{l}\text { I'uis } \\
\text { Segundo Martins (2016, } \\
\text { p. 64), Basso (2019, p. } \\
\text { 54) e Zampaulo (2019, p. } \\
\text { 127) }\end{array}$ & $\begin{array}{l}\text { Iw'if } \\
\text { (ILTEC) } \\
\text { Dicionário } \\
\text { Fonético. }\end{array}$ \\
\hline & & $\begin{array}{l}\text { I'ujJ } \\
\text { Segundo Bagno (2007, p. } \\
41 \text { ), acrescenta-se um s } \\
\text { 'chiado' em algumas } \\
\text { regiões do Brasil; Rio de } \\
\text { Janeiro, Pará e na ilha de } \\
\text { Florianópolis em Santa } \\
\text { Catarina). }\end{array}$ & \\
\hline
\end{tabular}

Fonte: Elaborada pelo autor da investigação. 
A tabela 1 foi elaborada para apresentar a pronúncia da palavra luz nas regiões de Lisboa, Rio de Janeiro e na variação geral do Brasil. O dicionário fonético ILTEC apresenta uma mesma pronúncia para as regiões de Lisboa e do Rio de Janeiro. Também ILTEC mostra que a pronúncia para o nome Luís ou Luiz é feita do mesmo jeito. Por outra parte, vários autores evidenciam nas suas publicações duas variantes existentes entre o Rio de Janeiro e os outros estados do Brasil. Essa variação entre o 'z' ou 's' ao final das palavras 'luz', 'Luís' e 'Luiz' que no Rio de Janeiro são chiadas e na maioria dos restantes estados não são chiadas.

Tabela 2. A tabela está baseada em uma amostra do corpus das 16 letras de samba enredo. Destaca-se a pronúncia da palavra luz na voz do cantor do samba-enredo.

\begin{tabular}{|c|c|c|}
\hline $\begin{array}{l}\text { Tema da letra de } \\
\text { samba-enredo da } \\
\text { Escola de Samba Beija- } \\
\text { Flor de Nilópolis. }\end{array}$ & $\begin{array}{l}\text { Estrofe onde o item } \\
\text { lexical 'luz' é usado } \\
\text { como parte da letra de } \\
\text { samba-enredo. }\end{array}$ & $\begin{array}{l}\text { Transcrição fonética dos } \\
\text { segundos } 22 \text { ao } 24 \text { do áudio da } \\
\text { letra de samba-enredo. } \\
\text { (Repetição dos } 1.16 \text { ao } 1.18 \text { ) }\end{array}$ \\
\hline $\begin{array}{l}\text { Samba Enredo } 1992 \text { - } \\
\text { Há um ponto de luz na } \\
\text { imensidão. }\end{array}$ & $\begin{array}{l}\text { Um ponto de luz } \\
\text { surgiu, oi! }\end{array}$ & $\begin{array}{l}\text { Ũ / p'õ.tu / d3I / l'ujJ / suh.z'iu /, } \\
\text { oj! }\end{array}$ \\
\hline
\end{tabular}

Fonte: Elaborada pelo autor da investigação.

A segunda tabela foi organizada para apresentar a pronúncia da palavra luz em uma das 16 letras dos sambas enredos analisadas. Na primeira coluna, foi colocado o nome do samba enredo e a data para a qual foi feita a composição. Em segundo lugar, temos colocado a estrofe onde o item lexical luz é usado como parte da letra do samba enredo. Por último, na terceira coluna foi especificado nos minutos em que aparece dita estrofe com a sua transcrição fonética baseada no sotaque carioca do cantor da Escola de Samba Beija-Flor de Nilópolis do Rio de Janeiro. 


\section{CONSIDERAÇÕES FINAIS}

A presente investigação, foi baseada no enquadramento teórico da Linguística Cognitiva, analisamos a polissemia do item 'luz' nos três dicionários Houaiss (2009), Aurélio (2010) e Michaelis (2015). Além disso, procuramos em Linguateca e em 'Letras.com' as ocorrências de 'luz' na linguagem-em-uso. Retomando a questão norteadora da pesquisa sobre quais são os diferentes sentidos que o item polissêmico 'luz' tem em um mesmo protótipo. O resultado encontrado foi que os dicionários apresentaram uma variedade de verbetes, mostrando assim o alto nível polissêmico da palavra. Por outra parte, os corpora lexicográficos evidenciam uma maior extensão para o lexema 'luz' nos verbetes de sentido metafórico, como já foi mostrado. Além disso, existem outras derivações por extensão metafórica. Em seguida, a segunda questão de investigação foi quantas ocorrências apresenta o item polissêmico 'luz' nas plataformas de CETEMPúblico. Como resultado dessa segunda questão norteadora deparamos que as ocorrências de 'luz' no CETEMPúblico foram de 16142 , demonstrando a frequência do seu uso neste meio discursivo. Na amostra de 100 ocorrências, encontramos uma pequena amostra para homonímia (1\%) e metonímia (7\%). Os excertos no sentido de generalização foram de $6 \%$, no sentido de especificação de $20 \%$ e no sentido metafórico de $63 \%$. Isso significa que temos à disposição uma amostra maior da linguagem-em-uso de 'luz' com sentido metafórico. Também notamos a frequência do uso de 'luz verde' como autorização positiva para a realização de coisas concretas nos diferentes ambientes pessoais ou profissionais. $\mathrm{Na}$ análise do nome 'Luz' permitiu-nos fazer outra proposta de rede de sentidos em representação do nível abstrato e do nível concreto. Por último, pesquisou-se quantas ocorrências tem o item 'luz' no corpus de letras de sambas-enredo da Escola de Samba Beija-Flor de Nilópolis entre 1980 e 2020. Como último resultado, nas letras de samba-enredo, foi evidente o uso metafórico da palavra 'luz'. Que, nesta percepção, a maioria arremete para o sentido de esperança como 'um ponto de luz surgiu', da religião em 'luz, divina luz' e para mostrar que uma pessoa é um modelo para a sociedade, temos a letra de samba-enredo de 1995 intitulada, Bidu Sayão e o canto de cristal, narrando que ela 'é festa, é luz, ...' Enfim, deixamos em aberto a 
possibilidade de fazermos uma investigação mais abrangente na Linguateca e de analisarmos de forma mais extensa e pormenorizada a polissemia do item luz noutras letras de samba-enredo.

\section{REFERÊNCIAS}

ABRANTES, Ana Margarida. 'Da vida e outras viagens...' A relevância das metáforas conceptuais na abordagem de uma língua estrangeira. In: Máthesis, 10, 2001, 319332. 2001a.

ABRANTES, Ana Margarida. Guerra, paz ou pacificação? Aspectos semânticos e pragmáticos do eufemismo na imprensa. In: Silva, Augusto Soares da (org.) (2001) Linguagem e cognição: a perspectiva da linguística cognitiva, Braga: Associação Portuguesa de Linguística e Universidade Católica Portuguesa, 79-98, 2001b.

BAGNO, Marcos. Nada na língua é por acaso: por uma pedagogia da variação linguística. São Paulo: Parábola Editorial. 1ª edição, 2007, 8ª reimpressão - outubro de 2019.

BAGNO, Marcos. Gramática de bolso do português brasileiro. São Paulo: Parábola Editorial. 1ª edição, 2013, 3ª reimpressão - outubro de 2018.

BASSO, Renato Miguel. Descrição do português brasileiro. Coordenação Tommaso Raso, Celso Ferrrezi Junior. - 1. Ed. - São Paulo: Parábola, 168p., 2019.

BATORÉO, Hanna Jakubowicz e SILVA, Augusto Soares da. Estudar o português como língua pluricêntrica no enquadramento da Linguística Cognitiva com foco nas variedades nacionais do PE e PB". In: TEIXEIRA E SILVA, Roberval; YAN, Qiarong; ESPADINHA, Maria Antónia; LEAL, Ana Varani. (eds.) 2012. IIISIMELP: A formação de novas gerações de falantes de português no mundo. China, Macau: Universidade de Macau. CD-ROOM.ISBN: 978-99965-1-035-9. 
BATORÉO, Hanna Jakubowicz. Linguística Portuguesa: Abordagem Cognitiva. Lisboa: Universidade Aberta. Livro em formato de CD-ROM. ISBN: 972-674-446-6., 2004a.

BATORÉO, Hanna Jakubowicz. The taboo of war and WAR metaphoric conceptualisation: song lyrics of the Portuguese colonial war. In: Silva, Augusto Soares da; Amadeu Torres, Miguel Gonçalves (eds.) - Linguagem, Cultura e Cognição: Estudos de Linguística Cognitiva, 2 vols. Coimbra: Almedina, Vol. 2: 185-202., 2004b.

BATORÉO, Hanna Jakubowicz. Como não "pôr o pé em ramo verde" ou do papel da polissemia na construção do sentido. In: Graça M. Rio-Torto, Olívia Figueiredo \& Fátima Silva (orgs.), Estudos em Homenagem ao Professor Doutor Mário Vilela. Porto: Faculdade de Letras do Porto, 237-251, 2005a.

BATORÉO, Hanna Jakubowicz. O Estudo do Português Europeu na mira da Linguística Cognitiva - uma experiência de 15 anos. In: Actas do XX Encontro da APL, Lisboa, 2005b.

BATORÉO, Hanna Jakubowicz. (2008) "As raízes do bota(-)fogo: construção de sentidos múltiplos. Evidência do Português Europeu", a publicar nas Actas do II Congresso sobre Metáfora na Linguagem e no Pensamento, no âmbito da comunicação coordenada: Processos Figurativos e o Léxico: a Interface Cognição/Morfologia, 21-24 de outubro, Fortaleza, Brasil, 2008.

BATOREO, Hanna Jakubowicz. As raízes de 'botafogo': construção de sentidos múltiplos em Português Europeu. Veredas - Revista de Estudos Linguísticos, 94106, 2011.

BATORÉO, Hanna Jakubowicz. Linguística Cultural e o Estudo do Léxico da Língua Portuguesa (PE e PB): A linguagem-em-uso, os sentidos múltiplos e as operações de perspectivação conceptual. In: Simões, Darcila; Paulo Osório; Cecília Mollica (orgs.) (2015) Contribuição à Linguística no Brasil: um projecto de vida. Miscelânia em 
homenagem a Cláudia Roncarati, Rio de Janeiro, 2015. Dialogarts, Faperj. 98-143. ISBN: 978-85-8199-032-3.

BATORÉO, Hanna Jakubowicz. On Ironic Puns in Portuguese Authentic Oral Data. How does multiple meaning make irony work? Chapter $5 \mathrm{In}$ : A. Athanasiadou \& $\mathrm{H}$. Colston (eds.). Irony in Language Use and Communication. John Benjamins. 109126, 2017. Paper edition ISBN 9789027209856. Electronic edition ISBN 9789027264824. DOI: 10.1075/ftl.1 https://benjamins.com/\#catalog/books/ftl.1/main

BREAL, Michel. Essai de sémantique. Science des significations. Paris: Gérard Monfort. (1924) [1897].

CETEMPÚBICO. Item lexical 'luz'. Disponível em: https://www.linguateca.pt/acesso/corpus.php?Corpus=CETEMPUBLICO. Acesso em: 26 de janeiro de 2021.

ESCOLA de Samba Beija-Flor de Nilópolis. Samba Enredo 1987 - As Mágicas Luzes Da Ribalta. Disponível em: https://www.letras.mus.br/beija-flor-rj/1732726/ Acesso em: 28 de dezembro de 2020.

ESCOLA de Samba Beija-Flor de Nilópolis. Samba Enredo 1990 - Todo Mundo Nasceu Nu. Disponível em: https://www.letras.mus.br/beija-flor-ri/709634/ Acesso em: 28 de dezembro de 2020.

ESCOLA de Samba Beija-Flor de Nilópolis. Samba Enredo 1992 - Há um ponto de luz na imensidão. Disponível em: https://www.letras.mus.br/beija-flor-rj/709635/ Acesso em: 28 de dezembro de 2020.

ESCOLA de Samba Beija-Flor de Nilópolis. Samba Enredo 1993 - Uni, Duni, Tê, a Beija-flor Escolheu, É Você! Disponível em: https://www.letras.mus.br/beija-florrj/709636/ Acesso em: 28 de dezembro de 2020. 
ESCOLA de Samba Beija-Flor de Nilópolis. Samba Enredo 1995 - Bidu Sayão e o Canto de Cristal. Disponível em: https://www.letras.mus.br/beija-flor-rj/709638/ Acesso em: 28 de dezembro de 2020.

ESCOLA de Samba Beija-Flor de Nilópolis. Samba Enredo 2000 - Brasil - Um Coração que Pulsa Forte. Pátria de Todos ou Terra de Ninguém. Disponível em: https://www.letras.mus.br/beija-flor-rj/120085/ Acesso em: 28 de dezembro de 2020.

ESCOLA de Samba Beija-Flor de Nilópolis. Samba Enredo 2001 - A Saga de Agotime, Maria Mineira Naê. Disponível em: https://www.letras.mus.br/beija-flor$\mathrm{rj} / 120084 /$

ESCOLA de Samba Beija-Flor de Nilópolis. Samba Enredo 2003 - O povo conta a sua história: "saco vazio não pára em pé" - a mão que faz a guerra faz a paz. Disponível em: https://www.letras.mus.br/beija-flor-rj/120087/ Acesso em: 28 de dezembro de 2020.

ESCOLA de Samba Beija-Flor de Nilópolis. Samba Enredo 2004 - Manôa - Manaus - Amazônia - Terra Santa... Que Alimenta O Corpo, Equilibra A Alma E Transmite A Paz. Disponível em: https://www.letras.mus.br/beija-flor-rj/77442/ Acesso em: 28 de dezembro de 2020.

ESCOLA de Samba Beija-Flor de Nilópolis. Samba Enredo 2010 - Brilhante ao sol do novo mundo, Brasília: do sonho à realidade, a capital da esperança. Disponível em: https://www.letras.mus.br/beija-flor-rj/1572681/ Acesso em: 28 de dezembro de 2020.

ESCOLA de Samba Beija-Flor de Nilópolis. Samba Enredo 2011 - Roberto Carlos: a Simplicidade do Rei. Disponível em: https://www.letras.mus.br/beija-florrj/1759521/ Acesso em: 28 de dezembro de 2020. 
ESCOLA de Samba Beija-Flor de Nilópolis. Samba Enredo 2012 - São Luís? 0 Poema Encantado do Maranhão. Disponível em: https://www.letras.mus.br/beijaflor-rj/1978509/ Acesso em: 28 de dezembro de 2020.

ESCOLA de Samba Beija-Flor de Nilópolis. Samba Enredo 2016 - Mineirinho Genial! Nova Lima, Cidade Natal. Marquês de Sapucaí, O Poeta Imortal. Disponível em: https://www.letras.mus.br/beija-flor-rj/samba-enredo-2016-mineirinhogenial-nova-lima-cidade-natal-marques-de-sapucai-o-poeta-imortal/ Acesso em: 28 de dezembro de 2020.

ESCOLA de Samba Beija-Flor de Nilópolis. Samba Enredo 2017 - A Virgem Dos Lábios de Mel - Iracema. Disponível em: https://www.letras.mus.br/beija-florrj/samba-enredo-2017-a-virgem-dos-labios-de-mel-iracema/ Acesso em: 28 de dezembro de 2020.

ESCOLA de Samba Beija-Flor de Nilópolis. Samba Enredo 2018 - Monstro É Aquele Que Não Sabe Amar (Os Filhos Abandonados da Pátria Que Os Pariu). Disponível em: https://www.letras.mus.br/beija-flor-rj/samba-enredo-2018-monstro-e-aqueleque-nao-sabe-amar-os-filhos-abandonados-da-patria-que-os-pariu/ Acesso em: 28 de dezembro de 2020.

ESCOLA de Samba Beija-Flor de Nilópolis. Samba Enredo 2019 - Quem Não Viu, Vai Ver... As Fábulas do Beija-Flor. Disponível em: https://www.letras.mus.br/beijaflor-rj/samba-enredo-2019-quem-nao-viu-vai-ver-as-fabulas-de-um-beija-flor/ Acesso em: 28 de dezembro de 2020

FERREIRA, Aurélio Buarque de Holanda. Dicionário da língua portuguesa. 5. Ed. Curitiba: Positivo, 2222 p. ISBN 978-85-385-4198-1., 2010.

GEERAERTS, Dirk. Prospects and problems of prototype theory. Linguistics. 27, 587-612, 1989. (republicado em Geeraerts 2006, cap. 1). 
HOUAISS, A.; VILLAR, M. S. Dicionário Houaiss de Língua Portuguesa. Elaborado pelo Instituto Antônio Houaiss de Lexicografia e Banco de Dados da Língua Portuguesa S/C Ltda. Rio de Janeiro: Objetiva, 1986p., 2009. ISBN 978-85-7302-9635

ILTEC - Instituto de Linguística Teórica e Computacional. Dicionário Fonético. Disponível em:http://www.portaldalinguaportuguesa.org/index.php?action=fonetica\&act=change \&region=rjx Acesso em: 21 de dezembro de 2020.

LAKOFF, George. Women, Fire, and Dangerous Things: What Categories Reveal about the Mind. Chicago: The University of Chicago Press, 1987.

LANGACKER, Ronald W. Foundations of Cognitive Grammar, Vol. 1: Theoretical Prerequisites. Stanford: Stanford University Press, 1987.

LOPES, Nei e SIMAS, Luiz Antonio. Dicionário da história social do samba. - 4ed. - Rio de Janeiro: Civilização Brasileira, 2020.

MARQUES, Maria Emília Ricardo. Introdução aos estudos linguísticos: interlocução e xadrez. Realização de Carlos Duarte; Tecnóloga Maria João Guerreiro. Lisboa: Universidade Aberta, 1996. Programa em vídeo (12 min., 14 seg.). Disponível em: https://vimeo.com/user34119652/review/151088387/5d3eb84a0e

MARQUES, Maria Emília Ricardo. Introdução aos estudos linguísticos: num quotidiano de metáforas. Realização de Carlos Duarte; Tecnóloga Maria João Guerreiro. Lisboa: Universidade Aberta, 1997. Programa em vídeo (12 min., 33 seg.). Disponível em: https://vimeo.com/user34119652/review/151087617/d9cf3451ef

MARTINS, Marco Antonio et al. Ensino de português e sociolinguística. 1. Ed., $1^{a}$ reimpressão. - São Paulo: Contexto, 170p., 2016.

MICHAELIS. Moderno dicionário da língua portuguesa. São Paulo: Editora Melhoramentos Ltda., 2015. ISBN: 978-85-06-04024-9 Disponível em: 
http://michaelis.uol.com.br/moderno/portugues/. Acesso em: 27 de dezembro de 2020.

MUSA, Alberto e SIMAS, Luiz Antonio. Samba de enredo: história e arte. - Rio de Janeiro: Civilização Brasileiro, 2010.

ROSCH, Eleanor e MERVIS, Carolyn B. "Family resemblances: studies in the internal structure of categories", Cognitive Psychology 7, pp. 573-605, 1975.

$\mathrm{ROSCH}$, Eleanor. Principles of categorization. In: Eleanor Rosch \& Barbara B. Lloyd (eds.), Cognition and Categorization. Hillsdale, N.J.: Lawrence Erlbaum, 27-48., 1978.

SCORSOLINI-Comin, F., Pacífico, S. M. R., \& Romão, L. M. S. "O que se vê pode não ser... Será?": o jogo de (re) velar sentidos em um samba-enredo. Raído, 5(9), 115-126, 2011.

SILVA Augusto Soares da. A Linguística Cognitiva. Uma Breve Introdução a um Novo Paradigma em Linguística. In: Revista Portuguesa de Humanidades, Vol. 1 - Fasc. $1-2,59-101,1997$.

SILVA, Augusto Soares da. Introdução. In: Augusto Soares da Silva (org.) Linguagem e Cognição: a Perspectiva da Linguística Cognitiva, Braga: Associação Portuguesa de Linguística e Universidade Católica Portuguesa, 1-18, 2001.

SILVA, Augusto Soares da. O poder cognitivo da metáfora e da metonímia. In: Revista Portuguesa de Humanidades, Vol. 7 - Fasc. 1 - 2, 13-75, 2003.

SILVA, Augusto Soares da. (2004a). Introdução: linguagem, cultura e cognição, ou a Linguística Cognitiva. In: Augusto Soares da Silva, Amadeu Torres e Miguel Gonçalves (org.) Vol. I: p: 1-18, 2004a.

SILVA, Augusto Soares da. Protótipos, imagens e metáforas, ou o experiencialismo da linguagem e do pensamento. In: A. Dinis e J. M. Curado (org.) Consciência e 
Cognição, Braga, Publicações da Faculdade de Filosofia de Braga, UCP, 79-96, 2004b.

SILVA, Augusto Soares da. O Mundo dos Sentidos em Português: Polissemia, Semântica e Cognição, Coimbra: Almedina, 2006.

SILVA, Augusto Soares da. Os estudos de Linguística Cognitiva do Português. Revista Portuguesa de Humanidades - Estudos Linguísticos. 11. 51-83, (2007).

ZAMPAULO, André. Os sons do português - uma introdução prática à fonética e à pronúncia da língua portuguesa. Routledge, 290p, 2019. ISBN 9781138225510.

\section{ANEXOS}

Anexo 1 - Dicionário Aurélio (2010)

luz

[Do lat. luce.]

Substantivo feminino.

1. Fís. Radiação eletromagnética capaz de provocar sensação visual num observador normal; radiação eletromagnética de comprimento de onda compreendido aproximadamente entre $4.000 \AA ̊$ e $7.800 \AA$.

2. Claridade emitida pelos corpos celestes:

"Um dilúvio de luz cai da montanha: / Eis o dia! eis o Sol!" (Antero de Quental, Sonetos, p. 137.)

3. Claridade emitida por corpos que não a possuem, mas que a refletem de outros; reflexo:

a luz dos planetas.

4. Claridade, luminosidade.

5. Qualquer dos objetos empregados como iluminantes (vela, lampião, lâmpada, etc.).

6. A claridade resultante do funcionamento de qualquer desses objetos:

Ótima a decoração do apartamento, sobretudo quanto aos efeitos de luz; 
"incerta e fina / Luz, que mal bruxuleia pequenina..." (Id., ib., p. 253).

7. Brilho, fulgor, cintilação:

a luz dos olhos.

8. Fig. Aquilo ou aquele que esclarece, ilumina ou guia o espírito: as luzes da fé;

"Sou o espírito, a luz!... tu és tristeza" (Id., ib., p. 263).

9. Fig. Faculdade de percepção; juízo, inteligência.

10. Fig. Esclarecimento, elucidação:

Sua crítica emprestou luz à obra.

11. Fig. Evidência, certeza, verdade:

"Da discussão nasce a luz" (prov.).

12. Fig. Ilustração, saber:

homem de muita luz.

13. Fig. Notoriedade, publicidade.

14. Fig. Influência (2):

Sem luzes estranhas não teria feito o que fez.

15. Anat. A cavidade existente no interior de um vaso ${ }^{1}$ (6), ou de órgão oco.

16. Constr. Espaço entre colunas, paredes, etc.; vão livre.

17. Mec. Folga ou distância entre duas peças, duas superfícies.

18. Bras. Espaço de terreno que, numa corrida, um dos corredores leva de dianteira a outro(s).

19. Bras. Espaço livre, nas construções urbanas, destinado ao recebimento da luz solar.

20. Bras. RJ Gír. de ladrões V. dinheiro (5). V. Iuzes.

Luz artificial. Fot. Qualquer luz que não provenha, direta ou indiretamente, do Sol. Luz atenuante. Fot. Teatr. Telev. A que reduz o contraste das sombras provocado pela luz principal (q. v.).

Luz básica. Fot. Luz difusa (q. v.).

Luz cinérea. Astr. Luz cinzenta.

Luz cinzenta. Astr. Luminosidade proveniente da luz refletida pela Terra na superfície lunar, e que se observa na região não iluminada do disco lunar, quando 
a Lua é visível sob a forma de um fino crescente; luz cinérea.

Luz circularmente polarizada. Ópt. Luz polarizada em que o vetor elétrico está sobre um plano que efetua um movimento de rotação uniforme em torno da direção de propagação da luz.

Luz cruzada. Fot. Teatr. Telev. A que provém de feixes de luz em diagonal.

Luz de chão. Teatr. A que provém de refletores fixos no chão.

Luz de fundo. Fot. Teatr. Telev. A que provém de refletores atrás da cena.

Luz de marcha. Mar. Dispositivo luminoso destinado a indicar, à noite, a velocidade do navio e as alterações ocorridas neste, segundo convenções próprias.

Luz de pino. Fot. Teatr. Telev. Luz zenital (q. v.).

Luz de realce. Fot. Feixe de luz dirigido sobre o rosto da pessoa a ser fotografada para the realçar alguns detalhes.

Luz difusa. Fot. A que ilumina sem provocar sombras ou contrastes acentuados; luz básica.

Luz dirigida. Fot. A que provém de uma ou mais fontes bem localizadas e ilumina um objeto de maneira não uniforme, provocando contrastes e sombras acentuados.

Luz do Tabor. V. onfalópsico.

Luz elipticamente polarizada. Ópt. Aquela em que o vetor elétrico gira uniformemente em torno da direção de propagação e a sua extremidade descreve uma hélice cilíndrica elíptica.

Luzes de navegação. Mar. Luzes que, por força de acordos internacionais relativos à segurança da navegação, toda embarcação é obrigada a mostrar em períodos de obscuridade, a fim de que as demais embarcações sejam informadas da direção do seu movimento e das suas dimensões. [Constam dos faróis de bordo (vermelho a bombordo e verde a boreste) e de uma ou duas luzes brancas (segundo o comprimento da embarcação) fixas no mastro de vante e no de ré.] Luzes de uma loja. Maç. O venerável mestre, o primeiro e o segundo vigilantes, o orador (3) e o secretário.

Luz fria. Fís. A que é emitida num fenômeno de luminescência. 
Luz infravermelha. Astr. Radiação eletromagnética de comprimento de onda ligeiramente maior do que o da luz visível.

Luz monocromática. Ópt. A que contém radiação de um único comprimento de onda.

Luz natural. Fot. A proveniente do Sol.

Luz negra. 1. Fís. Radiação ultravioleta com comprimento de onda entre $3.200 \AA$ e 4.000Å. 2. Teatr. Luz ultravioleta que se projeta sobre cenários ou figurinos executados em material fluorescente ou fosforescente, para destacá-los por inteiro do resto da cena, que permanece em completa escuridão.

Luz plano-polarizada. Ópt. Luz polarizada.

Luz polarizada. Ópt. Aquela em que o vetor elétrico vibra constantemente em um mesmo plano; luz plano-polarizada.

Luz principal. Cin. Fot. Telev. Feixe principal de luz de uma cena.

Luz terrestre. Astr. Luz refletida pela Terra no espaço, e que pode iluminar outros astros, especialmente a Lua.

Luz ultravioleta. Astr. Radiação eletromagnética de comprimento de onda ligeiramente menor do que o da luz visível.

Luz verde. 1. Ausência de obstáculos ou empecilhos; caminho aberto:

O Presidente deu ao líder do partido luz verde para promover os entendimentos. 2.

V. sinal verde.

Luz visível. Luz (1).

Luz zenital. Fot. Teatr. Telev. A que provém do teto ou do alto, iluminando a cena verticalmente; luz de pino.

Luz zodiacal. Astr. Luminosidade tênue que se estende na região do zodíaco, após o ocaso e antes do nascer do Sol, produzida pela reflexão da luz solar em partículas meteoríticas que se localizam próximo ao plano da eclíptica.

À luz de. Segundo o modo de ver, o critério, os princípios, de:

À luz da ciência tal fato é inconcebível.

A todas as luzes. Sob todos os aspectos; de todos os pontos de vista.

Dar à luz. 1. Parir (1 e 3):

Deu à luz uma bela menina; Está grávida, prestes a dar à luz. 2. Editar, publicar. 
Lançar luz sobre. Esclarecer, ilustrar, elucidar (alguma coisa, algum assunto).

Perder a luz. 1. Ficar cego; cegar. 2. Perder os sentidos; esmorecer.

Perder a luz da razão. Perder a razão; enlouquecer.

Vir à luz. V. vir a lume.

Receber a luz. Maç. Iniciar-se na maçonaria, i. e., retirar, o iniciado, a venda do obscurantismo.

Anexo 2 - Dicionário Houaiss (2009)

\section{Luz - datação 1041}

\section{Acepções}

- substantivo feminino

1 capacidade de visão

Ex.: perder a l.

2 a iluminação que procede do Sol durante o dia; luz do dia; claridade

3 claridade que difundem os corpos celestes, própria (no caso das estrelas) ou refletida (no caso da Lua, planetas etc.)

4 claridade ou clarão que produz fonte luminosa de tipos diversos (fogueira, lâmpada etc.)

5 Derivação: por metonímia.

objeto próprio para iluminar

Ex.: a luz do quarto queimou

6 Derivação: por metonímia.

fonte de luz us. como sinal para a navegação, trânsito etc.; farol, semáforo

7 Derivação: sentido figurado.

ponto de vista

Ex.: analisaram os fatos sob uma l. desfavorável

8 Derivação: sentido figurado.

ideia que ilumina a mente; esclarecimento, elucidação, informação

8.1 Derivação: sentido figurado. 
caráter de clareza, de evidência, de certeza, que alguma coisa oferece ao espírito Ex.: nada trará I. para esse impasse

8.2 Derivação: sentido figurado.

m.q. insight ('clareza súbita')

9 Derivação: sentido figurado.

faculdade de perceber as coisas; inteligência (freq. us. no pl.)

10 Derivação: sentido figurado.

ilustração; saber (freq. us. no pl.)

11 Derivação: sentido figurado.

conhecimento público

Ex.: a imprensa trouxe à l. fatos escabrosos

12 Derivação: sentido figurado.

brilho, fulgor

Ex.: vi em seus olhos a l. da cobiça

13 Derivação: sentido figurado.

pessoa eminente; luminar

14 Derivação: sentido figurado. Rubrica: religião.

iluminação espiritual que é atributo divino ou a incorporação da verdade divina; verdade suprema (esp. a doutrina cristã); a fé

15 Rubrica: artes plásticas.

qualquer área de um quadro, gravura ou desenho, representada como iluminada 16 Rubrica: anatomia geral.

espaço no interior de um órgão tubular, ger. a cavidade das artérias e dos intestinos; lume, lúmen

17 Rubrica: arquitetura.

abertura por onde a luz exterior penetra num recinto fechado (janela, claraboia etc.)

18 Rubrica: arquitetura, engenharia.

espaço entre colunas; vão livre

19 Rubrica: engenharia mecânica.

abertura ou espaço vazio; distância ou folga entre duas peças

RC: 106976

Disponível em: https://www.nucleodoconhecimento.com.br/letras/linguistica-cognitiva 
20 Rubrica: óptica.

toda radiação eletromagnética sensível à visão humana e cujos comprimentos de onda estão contidos na faixa entre 400 e 740 nanômetros aprox. [É comum utilizar o nome luz para regiões do espectro vizinhas mas não visíveis, como nos casos das regiões ultravioleta e infravermelha.]

a luzes

n substantivo feminino plural

Rubrica: filosofia.

21 conhecimentos advindos do exercício da razão na filosofia iluminista Obs.: inicial maiúsc.

\section{Locuções}

\section{- I. antissolar}

Rubrica: astronomia.

luminosidade difusa, mancha de luz no céu mal definida, arredondada ou alongada, num ponto sobre a eclíptica situado a $180^{\circ}$ do Sol; clarão antissolar, luminosidade antissolar

\section{- I. artificial}

Rubrica: fotografia.

a que se produz por processos técnicos e não provém direta nem indiretamente do Sol

\section{- I. branca}

Rubrica: óptica.

1 luz que se pode decompor num espectro contínuo de radiações de diversos comprimentos de onda

2 Derivação: por extensão de sentido.

qualquer radiação que produza a mesma sensação que a luz média do meio-dia

\section{- I. cinzenta}

Rubrica: astronomia.

luz solar refletida pela Terra e que, iluminando a parte da Lua não iluminada pelo Sol mas visível da Terra, permite distinguir o disco lunar inteiro quando a Lua se mostra sob forma de crescente 


\section{- I. circularmente polarizada}

Rubrica: óptica.

aquela em que o vetor elétrico das ondas eletromagnéticas está confinado a um plano transversal à direção de propagação da luz, e que efetua um movimento de rotação de tal modo que a extremidade do vetor elétrico de magnitude constante descreve uma curva helicoidal

\section{- I. de fundo}

Rubrica: fotografia, teatro.

luz difusa com que se ilumina o fundo da cena

\section{- I. difratada}

Rubrica: óptica.

luz que sofreu difração

\section{- I. difusa}

1 Rubrica: fotografia.

a que provém de muitas direções ou fontes, de tal modo que o objeto assim iluminado não tem seus contornos nítidos

2 Rubrica: pintura.

luz preferida pelos artistas impressionistas, em que os tons não apresentam extremos de claro ou escuro e as cores locais aparecem puras, sem modificação

\section{- I. dirigida}

Rubrica: fotografia.

a que, provindo de uma ou mais fontes bem localizadas, define vigorosamente contrastes e sombras no objeto assim iluminado

\section{- I. elipticamente polarizada}

Rubrica: óptica.

luz em que o vetor elétrico gira em torno da direção de propagação da luz com amplitude variável, de tal modo que sua extremidade descreve uma curva que, ao ser projetada sobre um plano transversal à direção de propagação, obtém uma elipse

\section{- luzes de navegação}

luzes que a lei determina sejam exibidas por navios e aviões durante o período 
compreendido entre o nascer e o pôr do sol, segundo convenções internacionais

\section{-I. fria}

Rubrica: óptica.

luz obtida por processos que não envolvam incandescência e, portanto, acompanhada de pouca ou nenhuma radiação infravermelha [É a luz emitida na luminescência.]

\section{- I. incidente}

Rubrica: óptica.

luz que incide diretamente sobre uma superfície

\section{- I. monocromática}

Rubrica: óptica.

aquela cuja radiação eletromagnética apresenta apenas um comprimento de onda

- I. natural

luz do dia, proveniente do Sol

\section{- I. negra}

Rubrica: óptica.

radiação eletromagnética com comprimento de onda entre 320 nm e 400 nm aprox., contida na região do raio ultravioleta

\section{- I. polarizada}

Rubrica: óptica.

aquela em que as vibrações do vetor elétrico da radiação eletromagnética estão confinadas a uma determinada direção

\section{- I. refletida}

Rubrica: óptica.

luz emitida de volta por uma superfície iluminada

\section{- I. refratada}

Rubrica: óptica.

luz desviada de sua direção inicial ao passar pela superfície que separa dois meios transparentes diferenciados por seus índices de refração

\section{-I. terrestre}

Rubrica: astronomia. 
luz refletida pela Terra no espaço; quando refletida sobre a Lua, denomina-se luz cinzenta

\section{- I. verde}

Derivação: sentido figurado.

autorização ou permissão para iniciar ou prosseguir algo (p.ex. um projeto)

\section{- I. zenital}

Rubrica: teatro, fotografia.

a que se coloca no teto do palco ou do estúdio com o propósito de iluminar em sentido vertical a cena ou o modelo fotografado

\section{- I. zodiacal}

Rubrica: astronomia.

clarão difuso, esbranquiçado ou amarelado, visível no plano da eclíptica antes do amanhecer (no leste) e depois do crepúsculo (no oeste), correspondente à luz solar difratada e refletida por partículas meteoríticas do sistema solar, dentro e fora da órbita da Terra

\section{- à I. de}

segundo o critério, o ponto de vista, as normas, os princípios, as leis de (p.ex., da ciência, das artes etc.)

\section{- ao apagar das I.}

na última hora; no final

Ex.: o único gol foi feito ao apagar das I.

\section{- dar à $\mathrm{I}$.}

1 parir (um filho)

2 Derivação: por extensão de sentido.

publicar (uma obra)

\section{- dar uma I.}

apresentar uma alternativa, ideia, saída para um problema, situação etc.

Ex.: dê uma I. para solucionar a questão

\section{- lançar I. sobre}

tornar claro, inteligível; explicar, elucidar

\section{- perder a I.}

RC: 106976

Disponível em: https://www.nucleodoconhecimento.com.br/letras/linguistica-cognitiva 
1 sentir que se obscurece a vista; ficar cego

2 Derivação: por extensão de sentido.

perder os sentidos; enfraquecer, esmorecer

- vir à $\mathrm{l}$.

1 vir ao mundo; nascer

2 Derivação: por extensão de sentido.

tornar-se conhecido; popularizar-se

Ex.: suas teorias só vieram à I. recentemente

3 ser editado, impresso, publicado; vir a lume

Ex.: Os Lusíadas vieram à I. em 1572

Coletivos: Luzerna, ribalta

Sinônimos/variantes: ver sinonímia de claridade, dinheiro e sapiência.

Antônimos: nevoeiro, sombra, treva, ver tb. antonímia de prática e sinonímia de escuridão e ignorância.

Homônimos: luz (fl. luzir); luzes (pl.) / luzes (fl. luzir).

Etimologia: Lūx, lūcis: 'luz, claridade, iluminação, dia'.

Anexo 3 - Dicionário Michaelis online (2015)

luz

sf

1 FíS A porção da irradiação eletromagnética à qual os órgãos da visão reagem e cujo comprimento de onda varia de 3.000 a 7.000 unidades angstrom.

2 Forma de energia radiante que, transmitida de um corpo luminoso ao olho, age sobre os órgãos da visão.

3 A sensação assim produzida.

4 Forma semelhante de energia radiante, como os raios ultravioleta, que não afeta a retina.

5 lluminação, claridade ou radiação luminosa provinda de uma fonte particular, como vela, tocha, lâmpada elétrica, fogueira ou qualquer substância em ignição. 6 A própria fonte de claridade, quando acesa, como lâmpada, farol etc. 
7 A iluminação da Terra, produzida pelo Sol; luz solar, luz do dia, luz natural. 8 Claridade que espalham os corpos celestes, quer irradiando raios luminosos próprios (como as estrelas), quer refletindo a claridade recebida de outro astro (como os planetas e os satélites): A luz da Lua refletindo-se no mar é um belíssimo espetáculo.

9 Qualquer luminosidade intensa e geralmente rápida; brilho, clarão, fulguração. 10 FIG Iluminação mental ou espiritual; clareza repentina na mente ou no intelecto; estalo, lampejo, insight.

11 FIG Conhecimento público; publicidade, notoriedade: O vício receia a luz. 12 FIG Soma de conhecimentos adquiridos; saber, ciência, erudição: Adoro conversar com ele, pois é um homem de muitas luzes.

13 FIG V visibilidade.

14 FIG Ideia que leva a ver ou a conhecer, que torna (algo) compreensível; alguma coisa que esclarece ou informa; aclaramento, elucidação, informação: Ela lançou uma nova luz sobre a questão.

15 ART PLÁST A parte de uma pintura, gravura ou desenho que representa objetos ou áreas sobre as quais a luz supostamente incide; em uma escultura, a parte que oferece uma superfície em que a luz possa se refletir.

16 FIG Algo que dá vida ou individualidade a uma pessoa; sinal, centelha de vida: A luz da natureza humana refulge em seus gestos de desapego e altruísmo. 17 REL Iluminação espiritual que é um atributo divino ou a corporificação da verdade divina: A ação divina explica-se no mundo pelo caminho da luz. 18 ARQUIT Abertura livre sob um arco ou uma abóbada.

19 ARQUIT Meio de admissão de claridade ( $p$ ex, um compartimento de janela). 20 ARQUIT Em portas e janelas, distância livre entre ombreiras e entre verga e peitoril ou soleira.

21 ARQUIT Distância entre dois elementos consecutivos de sustentação de uma estrutura; vão livre.

22 TECN Espaço ou folga entre duas peças ou duas superfícies.

23 Diâmetro na boca de um cano, tubo etc.; diâmetro interior.

24 Distância compreendida entre o rabo de um e a cabeça de outro cavalo, que 
um parelheiro leva de dianteira a outro.

25 COLOQ Vdinheiro.

26 ANAT Espaço ou cavidade dentro de uma estrutura tubular; lume, lúmen.

luzes

sf pl

FILOS [com inicial maiúscula] Na filosofia iluminista, apego à ideia de progresso e crença na razão, nos efeitos da instrução e no pensar e julgar por si próprio.

EXPRESSÕESLuz alta, TEAT: luz suplementar, proveniente de refletores instalados em planos altos, que incide sobre o cenário.

Luz amarela, SEMIOL: Vsinal amarelo.

Luz angélica, ARQUIT: em uma janela gótica, luz triangular formada pelo arco da janela, um arco de um segmento inferior do traçado e o corrimão de um segmento superior do traçado.

Luz antissolar, ASTR: luminosidade difusa e muito fraca; mancha de luz de baixa definição em um ponto sobre a eclíptica, na direção oposta ao Sol; clarão antissolar; luminosidade antissolar.

Luz artificial: a que se produz por processos técnicos quando não há luz solar. Luz ativa, FOT: luz capaz de provocar mudanças químicas em um material, como um filme; luz atuante.

Luz atuante, FOT: Vluz ativa.

Luz branca, FÍS: aquela formada por uma mistura de cores diversas, cada uma das quais com um comprimento de onda diferente.

Luz cinérea, ASTR: Vluz cinzenta.

Luz cinzenta, ASTR: luminosidade que aparece no lado não iluminado do disco lunar quando a Lua é visível, sob a forma de um fino crescente; luz cinérea. Luz coerente, Fís: luz que parte do mesmo ponto luminoso da mesma fonte luminosa, de modo que seus raios coincidem em comprimento de onda, fase de vibração e plano de vibração.

Luz crua: iluminação direta que, ao incidir sobre um objeto, produz forte contraste e sombras claramente definidas.

Luz cruzada, ARQUIT: aquela cuja origem se encontra em fontes não situadas 
diante umas das outras, como, por exemplo, a luz de janelas em paredes adjacentes.

Luz de âncora, NÁUT: luz ou farol colocado na extremidade da proa de uma embarcação, para iluminar o ferro e a amarra.

Luz de aviso: sinalização de aviso que geralmente indica cuidado diante da presença de algum perigo.

Luz de cornija, ARQUIT: iluminação indireta, que se dirige para baixo a partir de uma cornija interna situada em um canto do teto.

Luz de freio: luz traseira de um veículo que é ligada por um contato elétrico ativado pelo pedal de freio.

Luz de fundo, TEAT, TV: luz difusa, destinada a iluminar o fundo da cena. Luz de manobra, NÁUT: equipamento que tem por finalidade indicar, à noite, a velocidade de uma embarcação e as alterações que venham a ocorrer nela. Luz de navegação, NÁUT: luz ou farol convencional que uma embarcação utiliza do pôr do sol ao nascer do dia, indicando seu rumo ou sua condição de navegação.

Luz de obstáculo: luz de aviso que, colocada em pontos altos de uma cidade (geralmente em edifícios), serve para sinalização a aviões.

Luz de pino, FOT, TEAT, TV: Vluz zenital.

Luz de sanefa, ARQUIT: iluminação indireta, que se dirige para cima ou para baixo e que provém de uma fonte de luz oculta por uma placa horizontal.

Luz difusa, Fís: a que não resulta de raios de luz diretos e que, por isso, não acusa nitidamente as sombras, como ocorre nos dias nublados.

Luz dirigida, FOT: aquela que, proveniente de uma ou mais fontes bem localizadas, provoca contrastes e sombras que ajudam a perceber quais objetos estão mais próximos e quais estão mais distantes, bem como a diferenciar superfícies lisas de superfícies ásperas.

Luz do chão: luz solar refletida por superfícies situadas abaixo do plano do horizonte.

Luz estroboscópica, TEAT, TV: tipo de iluminação obtido por meio de um sistema de flashes eletrônicos que se alternam, geralmente a intervalos regulares, 
segundo um padrão previamente programado.

Luz fria, Fís: aquela que é proporcionada por lâmpadas fluorescentes e a vapor de mercúrio, e que não produz calor.

Luz infravermelha: luz na qual os raios ficam logo abaixo da extremidade vermelha do espectro visível.

Luz intensa pulsada, MED: luz emitida aos pulsos (simples, duplos ou triplos) com intervalos variáveis, usada no tratamento de lesões vasculares da face, para a eliminação de rugas finas, cicatrizes superficiais, epilação etc.

Luz intermitente: luz com lampejos a intervalos regulares, de frequência igual ou superior a 120 lampejos por minuto.

Luz monocromática, FíS: luz de um só comprimento de onda ou frequência, que, portanto, não pode ser decomposta em cores espectrais.

Luz natural, ASTR: luz do dia, que provém do Sol.

Luz negra, FíS: luz produzida por lâmpadas de descarga que emitem raios ultravioleta e que, por realçar a cor branca em cores fosforescentes, é muito usada em teatros, onde é projetada sobre cenários, figurinos e objetos de cena feitos em material fosforescente.

Luz planopolarizada, Fís: Vluz polarizada.

Luz polarizada, FíS: luz na qual, em consequência da reflexão ou transmissão através de certos meios, as vibrações se encontram todas em um único plano, transverso ao raio, em vez de em todos os planos; luz planopolarizada.

Luz pulsada: emissão eletromagnética de luz usada no tratamento estético da pele, para diminuir manchas, rugas de expressão, pequenos vasos sanguíneos, flacidez etc.

Luz refratada: raios de luz que sofreram mudança de sua direção inicial ao passarem de um meio transparente para outro de densidade desigual.

Luz terrestre, ASTR: luz refletida pela Terra no espaço.

Luz ultravioleta, ASTR: radiação entre comprimentos de onda que variam de cerca de 10 a 380 nanômetros.

Luz verde: a) SEMIOL Vsinal verde; b) FIG caminho livre, sem obstáculos, para começar ou dar continuidade a alguma coisa já iniciada. 
Luz vermelha, SEMIOL: Vsinal vermelho, sinal fechado.

Luz zenital, FOT, TEAT, TV: a que provém do teto do palco ou do estúdio, e que ilumina verticalmente a cena, o ator ou o modelo fotografado; luz de pino.

Luz zodiacal, ASTR: luminosidade esbranquiçada e tênue que se estende na região do zodíaco, depois do anoitecer e antes do amanhecer, e que é produzida pela reflexão da luz solar em partículas meteoríticas que se localizam próximo ao plano da eclíptica.

À luz de: segundo as normas, as regras, os princípios ou pontos de vista de: Sua tese aborda o cotidiano à luz da filosofia.

A todas as luzes: sob todos os aspectos.

Ao apagar das luzes: a) no fim do dia; b) POR EXT em momento impróprio, devido ao fato de as atenções estarem voltadas para outros assuntos: Ao apagar das luzes do mandato presidencial, em plenas festas de fim de ano, o governo federal divulgou mais um pacote fiscal; c) na última hora.

Dar à luz: a) parir (um filho); b) POR EXT publicar (um livro).

Dar uma luz: apresentar alguma solução para um problema, uma situação etc.: Trate de dar uma luz aqui, pois estamos todos enrascados.

Lançar luz sobre: tornar claro; esclarecer, elucidar.

Perder a luz: a) ficar com a vista turva; ficar cego; b) POR EXT perder os sentidos; perder o ânimo, o entusiasmo.

Perder a luz da razão: ficar louco, tornar-se doido, perder o tino.

Ver uma luz no fim do túnel: começar a vislumbrar alguma esperança ou possibilidade de solução para um assunto complicado.

Vir à luz: a) vir ao mundo; começar a existir; nascer; b) adquirir popularidade; tornar-se conhecido: Sua obra poética só veio à luz quando não se interessava por mais nada.

ETIMOLOGIA lat lucem.

Anexo 4 - Corpus das ocorrências do item 'luz' em CETEMPúblico.

\section{Corpus das ocorrências de CETEMPúblico}


Resultado da procura

26 de janeiro de 2021

\section{Corpo: CETEMPúblico 1.7 v. 11.2}

Pedido de uma concordância em contexto

Procura: item "luz"

16142 ocorrências.

A plataforma de CETEMPúblico apresentou uma amostra aleatória de 8000 das 16142 ocorrências encontradas.

Para esta pesquisa, escolheu-se uma amostra de 100 das ocorrências disponibilizadas pela plataforma descrita acima.

1. par=ext512973-soc-96b-2: -- O PÚBLICO revela que o Ministério da Economia deu luz verde à reconversão da antiga Celulose do Caima, em Albergaria-a-Velha, numa moderna unidade de reciclagem de papel velho, sem que o Ministério do Ambiente se tenha pronunciado sobre o projecto em tempo útil.

2. par=ext1077374-clt-93a-2: Voltei a acender a luz.

3. par=ext1222104-des-98a-2: O encontro entre Alex Corretja, cabeça de série no 14, e Hernan Gumy (106을 ATP) foi interrompido por falta de luz com o marcador em 1-6, 7-5, 7-6 (7-4) e 4-5 (30-40) favoráveis ao argentino.

4. par=ext539583-soc-91b-2: Jorge Rangel fez questão, no entanto, de salientar que a última palavra, neste processo, cabe à $A L$, que ainda este mês deverá votar, em sessão plenária, a proposta do Executivo, para obter luz verde, porém, o documento necessita de maioria qualificada, correspondente ao voto de pelo menos 16 dos 23 deputados.

5. par=ext1563927-clt-soc-93a-2: «Pensei que havia qualquer coisa que podia ser inventada para aproveitar essas fontes de luz, em vez de as deitar fora. "

6. par=ext585546-nd-96a-1: Depois seguiram-se outras melhorias, como por exemplo a luz eléctrica nos lugares mais afastados da freguesia.

7. par=ext352239-soc-94a-2: Alfaia é acusado pela actual administração de ter 
levado os restantes membros deste órgão, sobretudo os administradores não executivos Guimarães Lobato (presidente) e Sá Machado (vice-presidente) a darem luz verde a um negócio (FSE) que se revelou um fracasso monumental para a empresa, dando origem a um processo judicial que está a ser investigado pela Procuradoria-Geral da República.

8. $<\mathrm{p}>$ : , de uma resposta da Câmara de Lisboa. Com o apoio da oposição de centro-direita italiana Prodi tem «luz verde» para a Albânia O primeiro-ministro italiano, Romano Prodi, abandonado pelos seus aliados comunistas na questão da 9. par=ext511218-nd-98b-1: Coordenada por Jorge Couto, actual presidente do Instituto Camões, e pelo almirante brasileiro Max Justo Guedes, esta exposição, destinada a posterior itinerância, terá um carácter marcadamente didáctico, procurando dar a conhecer os primórdios da presença portuguesa no Brasil à luz da historiografia contemporânea.

10. par=ext326461-soc-98b-2: Os efeitos de luz gerados pela pirotecnia serão mais de 30 mil, nesse aparentemente curto espaço de tempo.

11. par=ext322623-soc-93a-1: O primeiro debate sobre a cor e a luz da cidade de Lisboa vai ter lugar na segunda quinzena de Março, reunindo na capital especialistas portugueses e estrangeiros.

12. par=ext1346144-soc-95a-2: Em todos eles, falta a luz doméstica, a água canalizada, o saneamento, o comércio, ou mesmo as escolas ou a creche.

13. par=ext1545384-soc-94b-1: Na verdade, a travessia nocturna do salar, sob a luz prateada e difusa da lua cheia, viria a constituir um dos pontos memoráveis da expedição.

14. par=ext441200-clt-94b-1: «Titina Canta B. Leza», lançado em Paris no ano passado e mais recentemente distribuído entre nós, devolve à luz a figura do grande compositor crioulo, ao mesmo tempo que marca o regresso em força de Titina aos palcos do mundo.

15. par=ext17949-clt-soc-94b-1: Posto isto, vamos às classificações da prova $n^{\circ}-3$ do Supertorneio -- 94, o problema " Nem tudo o que luz é ouro ", de autoria de L.S., de Coimbra.

16. par=ext157250-clt-soc-93a-2: E, num femtossegundo, a luz propaga-se 
apenas 10 mícrons.

17. par=ext1422488-soc-96a-2: É uma linda maneira de ver a civilização à luz de Deus».

18. par=ext374140-clt-94b-1: Confessa-se surpreendido com a qualidade dos actores portugueses, adorou a luz de Lisboa, tem pena que os filmes portugueses não sejam lançados em Itália e explica porque gostou tanto de «Afirma Pereira», o romance de Tabucchi que o trouxe à «cidade branca» para o passar à tela.

19. par=ext237467-soc-97b-2: Bilotta já tinha dado que falar, salienta o mesmo diário, por ter feito com que uma mulher desse à luz uma rapariga que era, na realidade, filha genética da sua irmã -- que tinha morrido deixando um embrião congelado.

20. par=ext1529369-soc-93a-1: Apenas com os 30 contos de subsídiodesemprego, a família atravessa a crise da seca sem ver luz no fim do túnel, com os filhos mais velhos, de 15 de 16 anos longes da escola e os mais novos, de 9 e 4 anos, a comerem batatas fritas com ovos estrelados.

21. par=ext1041917-soc-95b-1: Dois búlgaros foram presos em Salónica, Grécia, por terem tentado vender a filha recém-nascida de uma compatriota sua ainda internada na maternidade onde acabara de dar à luz, confirmou ontem uma fonte policial local.

22. par=ext1116988-clt-94a-1: Lançada no nosso país um pouco antes da época natalícia, a nova Sony SC5 é um equipamento que segue a filosofia do bem sucedido modelo Sharp, mas, talvez porque o monitor de cristais líquidos da Sony é um pouco menos brilhante do que o seu opositor, foi também montado um visor óptico que, ao contrário do monitor LCD, não é afectado pelo aumento da luz ambiente.

23. par=ext1334850-pol-95b-1: Tanto mais imperdoável quanto a expressão surge no livro anual do MDN, cujos «autores» deveriam saber que em Timor se luta contra a ocupação ilegal de um território do qual Portugal é, à luz do Direito Internacional, a potência administrante.

24. par=ext1042984-opi-97b-1: Sendo assim, o que é triste é que Portugal, que aceitou ser um dos medianeiros no processo de paz angolana sabendo de 
antemão que as suas relações com Angola não podem ser vista apenas à luz fria desta nova «realpolitik» mundial, se disponha, no entanto, a ser o seu executante fiel, venerando e obrigado.

25. par=ext246694-clt-92b-2: O outro elemento fundamental eram meios tecnológicos de luz e de imagem, com um gigantesco quadrado (10 metros de cada lado) , com 600 néons, e um conjunto de monitores de vídeo, 15 suspensos e 20 sobre o estrado, estes dispondo-se variavelmente, sugerindo por exemplo cruzes, uma porta de convento ou o leito de morte de Francisco .

26. par=ext340409-soc-95a-2: Ainda em Abril do ano passado, numa visita às instalações madrilenas daquela empresa, o PÚBLICO pode ver os 20 equipamentos à espera, segundo a Cemusa, da luz verde do município alfacinha para seguirem para Lisboa.

27. par=ext864694-soc-92a-1: A sua exposição «Gastão 92» -- um conjunto de fotografias e desenhos, iluminados através de um sistema original de reflexão da luz solar -- estava destruída, apenas um dia depois de ter sido inaugurada.

28. par=ext13998-eco-93b-2: O Banco de Portugal não perde ainda a ocasião para lembrar que, ainda que a inflação tenha continuado a reduzir-se em Maio, apresentado mesmo o seu mais baixo valor homólogo dos últimos vinte anos $(5,7$ por cento) , a evolução salarial mantêm-se «insuficiente à luz da actual taxa média de crescimento salarial na Comunidade (cerca de quatro por cento) " .

29. par=ext1533079-opi-98a-1: Para muitos, a decisão do presidente do Metz, à luz do que o futebol é hoje, não faz qualquer sentido, porque é preciso ganhar a todo o custo e tem que se contar com os erros dos árbitros, das Comissões Disciplinares e por aí adiante.

30. $<p>$ : aplicarem uma bofetada de ressonância mundial na política nuclear de Jacques Chirac. Nova fase diplomática Câmara lança debate sobre luz e cor de Lisboa O primeiro debate sobre a cor e a luz da cidade de Lisboa vai ter lugar. 31. par=ext465261-pol-93a-2: E o CDS não reconheceu qualquer validade ao julgamento, que considerou «uma farsa política, à luz do direito internacional». 32. par=ext1215682-soc-94a-1: Que, além da descoberta de outros exemplares, podem fornecer mais informações sobre a história local à luz da evolução dos 
estudos epigráficos.

33. par=ext1028931-nd-91a-2: A doente confirma se está a ver uma «luzinha redonda vermelha no meio", recebe a indicação para não piscar os olhos nem se mexer, e é então enviado um feixe de luz azul que vai excitar as partículas fluorescentes e que corre o eixo do olho durante 20 segundos, após o que já pode fechar os olhos.

34. par=ext1228513-nd-92a-2: Por certo algum antepassado de Brown, e ainda por cima escrito antes de Jerry ser a luz dos olhos do próprio pai.

35. par=ext424297-eco-92a-1: «É apenas uma questão de obter luz verde para um acordo, ou manter algo no qual não se chegou a consenso» afirmou o embaixador.

36. par=ext451946-pol-96b-1: A disponibilidade que terá sido afirmada pelo governo para discutir uma eventual transferência interna de Almeida Serra para outra direcção-geral, não parece ter sido ouvida pela Comissão, sobretudo à luz da pressão exercida por Bonino para se ver livre do alto funcionário português. 37. par=ext41837-nd-93a-2: «O diabo deve estar satisfeito com os meios de comunicação que difundem a imoralidade, mas age de maneira imperceptível, pois o anjo das trevas prefere ser confundido com o anjo da luz», observava, por sua vez, D. Boaventura Kloppenburg, bispo de Novo Hamburgo, Rio Grande do Sul, e estudioso de fenómenos sobrenaturais.

38. par=ext948361-des-93b-2: Ao fim da tarde, a organização da prova teve de interromper duas das partidas, desta vez, devido à falta de luz natural.

39. par=ext1056834-pol-93a-2: Tenho a impressão de vêr finalmente uma luz de esperança

40. par=ext822802-soc-97b-1: Banhado pela luz poente, o seu granito toma a cor do bronze e as figuras singelas que foram esculpidas no pequeno pórtico parecem ganhar vida.

41. par=ext1256946-soc-91a-2: Assim que foram encontrados os primeiros vestígios, as escavações pararam e a direcção do Parque chamou pedreiros de Conímbriga para trazer as ruínas à luz do dia.

42. par=ext1407982-clt-95b-1: Uma fractura no tornozelo fê-lo dizer adeus à farda 
e partir errante em direcção à música e a uma luz que só ele via.

43. par=ext420172-soc-96b-2: Seguem-se as «três viagens» dos aspirantes, que simbolizam: o deambular para a luz, o caminhar da «câmara escura» da morte para a «grande luz» e a vida nova, antes de os seus olhos avistarem o mistério interior da loja (...)

44. par=ext1166755-nd-95a-2: Porque não são testados à luz de todos os cidadãos?

45. par=ext1482389-clt-97a-2: Mas, quando em Outubro de 1955 leu na agora lendária Six Gallery o seu poema «Howl» / «O Grito», dedicado a Carl Solomon, dava à luz a bíblia do movimento «beat».

46. par=ext1516332-clt-96a-2: $E$, à luz destas entrevistas, os investigadores concluem que «o facto de ter um baixo nível de resposta ao álcool aos 20 anos de idade constitui um preditor relativamente potente do desenvolvimento ulterior de dependência ao álcool».

47. par=ext295170-nd-95b-1: Os relatos dos sobreviventes contidos neste documentário da Antenne 2 francesa assemelham-se aos ouvidos aos de Hiroxima: a luz ofuscante do Inferno, mortos-vivos a deambularem, com a pele e pedaços de carne a caírem mal se lhes tocasse, os destroços fazendo tábua rasa de milhares de edifícios.

48. par=ext1153742-clt-soc-93b-1: Pelo facto de o espaço ser tão vasto, são necessários 4,3 anos para a luz da estrela mais próxima, Alfa Centauri -- na Constelação do Cruzeiro do Sul, chegar à Terra.

49. par=ext317807-soc-94a-2: Mas vê-se a luz ao fundo do túnel.

50. par=ext129684-eco-93a-1: À luz de uma verdadeira política de concorrência, a Comunidade deveria participar na afectação dos recursos produtivos, através do financiamento da produção nas regiões para onde se pretende encaminhar o investimento, e na orientação dos auxílios nacionais para essas mesmas regiões. 51. par=ext640839-soc-97b-2: Imersa na luz negra que será usada no evento, a decoração brilhará no escuro.

52. par=ext1417166-soc-92b-1: O assalto ocorreu à luz do dia e os piratas pareciam bem informados sobre a carga que seguia a bordo do Mild Splendor. 
53. par=ext769884-opi-96a-2: Gostaria de deixar aqui um apelo, não só como cidadão preocupado, mas também como aprendiz de investigador da sociologia, para que deixe de se atender preocupações individuais susceptíveis de se ferir na identidade global de que é feita a sociedade por estes pequenos memorandos de histórias de vida, feitos à luz de um contexto societal peculiar.

54. par=ext573750-nd-91a-2: As neblinas, os relevos, as distâncias, criam desigualdades na recepção da luz, mas tais inconvenientes não podem ser atribuídos a qualquer parcialidade do farol, nem sequer o facto de, iluminados unilateralmente, os objectos conservarem uma face oculta.

55. par=ext1289980-pol-94a-1: Questões como a nacionalidade e o futuro dos funcionários públicos virão à luz do dia.

56. par=ext634493-clt-soc-93a-2: Para testar esta conclusão, tornava-se necessário observar a luz de uma estrela distante, que se avistasse numa direcção muito próxima de um corpo de grande massa.

57. par=ext1519150-com-98a-1: E, a esta luz, melhor se entenderão os contornos do negócio com o Teleport Group, no qual a TCl e outras empresas aceitaram trocar os seus 66 por cento no respectivo capital por uma fatia de 10 por cento das acções da AT \& T.

58. par=ext1408918-clt-93a-1: à luz destas páginas de Octávio Paz, terá que ser o exercício de uma crescente cidadania democrática em múltiplos mundos -contra a homegeinização produtivista e burocrática de qualquer «fim da história» mais ou menos militarizado, como contra o perigo totalitário resultante do terror fundamental que tenderá a acompanhar um pouco por toda a parte a generalização da experiência de uma imagem da Terra (ou tão-só talvez dos recursos e respectivos modos de emprego adquiridos) como em vias de extinção. 59. par=ext1566709-soc-93b-1: Mau aproveitamento da luz natural. 60. par=ext1017110-soc-95b-2: Com todos os defeitos que possa ter, o autocarro continua a apresentar, à luz dos critérios economicistas da STCP, vantagens incontornáveis.

61. par=ext572167-pol-91b-1: O Uganda continua o mesmo Uganda de outrora, bastando apenas esgravatar um pouco à superfície para que os assassinos 
surjam em plena luz do dia.

62. par=ext1404968-opi-98a-1: Uma leitura que se recomenda e que tem artigos tão interessantes como «Reinstalação da Aldeia da Luz e realojamento da população» ou «Plano de Pormenor da nova Aldeia da luz».

63. par=ext1330565-pol-93b-2: Pela primeira vez em muitos anos, adormeço com a luz acesa.

64. par=ext308154-soc-91b-2: «Viagem a Lisboa» é o nome do espectáculo de luz que a Telecom Portugal vai oferecer à população entre as $18 \mathrm{~h} 30$ e as $19 \mathrm{~h} 00$. 65. par=ext1562745-clt-93a-1: É a «stand in» de Winona Ryder: tem a mesma altura e o mesmo tipo de rosto que a intérprete de Blanca e é ela que substituiu a vedeta quando é preciso medir a luz, calcular as distâncias de foco.

66. par=ext819690-pol-91a-1: «Quando abordar o capítulo sobre a perestroika, podeis fazer uma ideia, à luz deste exemplo, dos problemas que é preciso enfrentar».

67. par=ext332969-nd-94b-2: Os desvios históricos que sofreu a Revolução de Abril são entendíveis à luz desse jogo, algo criminoso, que constitui a luta do poder pelo poder.

68. par=ext624928-clt-93b-1: As janelas estão tapadas com móveis (felizmente há a luz eléctrica).

69. par=ext1556194-pol-95b-1: É bom recordar que esta certeza não advém apenas da aparente luz verde da Casa Branca.

70. par=ext1500961-eco-97b-2: A reafectação prevista pelo Executivo, segundo o documento entregue à Comissão Europeia em Julho, é para cerca de 60 milhões de contos a atribuir, mas não passa de proposta enquanto não receber luz verde de Bruxelas.

71. par=ext503743-clt-94b-2: É mantido o espírito da casa, tanto quanto possível, mas as janelas são tapadas para evitar a luz natural e criar mais área de exposição.

72. par=ext1404510-clt-soc-94b-1: Menor que uma unha, este mecanismo minimal tem um sensor óptico nos seus redondos olhos que o faz mover-se em direcção a fontes de luz, podendo vir a ser o antecessor de máquinas 
microscópicas habilitadas para viajar nas veias humanas.

73. par=ext565234-soc-93a-2: A CCRN diz agora aguardar que «os vícios sejam corrigidos", ou seja, que os promotores do empreendimento Ihe solicitem a licença prévia de localização que deveriam ter pedido anteriormente e que o projecto se possa tornar viável à luz do PDM portuense.

74. par=ext426477-clt-soc-94a-1: A vacina experimental contra a malária desenvolvida pelo investigador colombiano Manuel Patarroyo é a primeira a ver a luz num país em vias de desenvolvimento.

75. par=ext1005768-nd-94b-1: Pode-se e deve-se viver na miséria e na degradação, bastando olhar a luz divina, sob a forma de um Papa que aprendeu a compensar os exércitos de miseráveis com as suas generosas e incansáveis aparições -- a suprema manipulação.

76. par=ext897431-nd-98b-1: A luz verde da Comissão Europeia ao Viagra está dada, mas os comprimidos azuis vão demorar um a três meses a chegar às farmácias portuguesas.

77. par=ext398947-nd-94a-1: Por vezes, a ausência de luz.

78. par=ext1536548-soc-91a-1: Apesar de ostracizada pela população da aldeia remota onde vive, nunca perde a fé no seu santo e convence-se de que vai dar à luz um novo Messias.

79. $<\mathrm{p}>$ : anos em Timor-Leste; </li >-- em segundo lugar, os Governos dos Estados Unidos, que deram luz verde à invasão de 7 de Dezembro de 1975 e tem vindo a conceder ajuda militar a apoio político para

80. par=ext204071-nd-93b-1: É também a geração dos que procuram a luz do rosto de Deus nas lágrimas dos sem consolação, daqueles que não desistem da justiça com alma e corpo para a misericórdia e a paz

81. par=ext806622-nd-91b-1: Quase ninguém a conhece e muito menos o local onde fica: mesmo atrás da cidadela de Cascais, a antiga fortaleza de Nossa Senhora da Luz encerra diversos tesouros arqueológicos que estão agora a voltar à luz do dia.

82. par=ext190821-soc-98a-2: Como tive o ensejo de ler, em vários artigos dados à luz da publicidade pelo Prof. Galopim, na imprensa nacional, àquele rochedo 
andam, sem dúvida, ligados ritos e cultos antigos que a tradição do lugar, teimosamente, tem perpetuado na memória dos vivos, geração após geração. 83. par=ext613530-nd-94b-2: É assim que as coisas se vão passando alegremente, neste país, cujos responsáveis decidiram navegar numa total irresponsabilidade política que quase parece uma cegueira, quem sabe se por demasiado tempo de exposição à luz dos holofotes e dos «flashes».

84. par=ext1021917-clt-96b-1: Uma tem dez pequenas caixas de luz com nomes de lugares onde ocorreu o genocídio.

85. par=ext680483-pol-94a-2: Até o sobrinho do dono do restaurante, Michel, usou da palavra para dizer que se recordava do tempo em que Bota foi presidente da Câmara de Loulé, assistiu à inauguração da luz eléctrica em Alte, "donc», também ali foi prestar o seu depoimento.

86. par=ext1437795-soc-93b-2: Não havia cura, ainda se estava na fase de investigação; apenas se anunciava uma ténue luz ao fundo do túnel, relacionada com os projectos de investigação da doença de Alzheimer.

87. par=ext302435-soc-95a-2: Com quase vinte anos, o projecto foi demorando a concretizar-se e quando, finalmente, recebeu luz verde, acabou por encalhar nas dificuldades enfrentadas pelos Estaleiros de S. Jacinto, construtores da embarcação, pelas dificuldades burocráticas suscitadas pelo controlo dos inertes a extrair do rio e pela constituição da sociedade mista, formada pelos municípios de Caminha e de A Guarda, que irá gerir a exploração do empreendimento. 88. par=ext252342-soc-97a-1: Em silêncio e à luz de centenas de velas -símbolos de solidariedade e de memória.

89. par=ext579337-nd-91b-1: Não faz sentido estar a julgar, à luz dos conceitos actuais de produção automóvel, um carro que continua a seguir orgulhosamente todas as ideias que, em 1959, o tornaram num dos maiores sucessos de sempre da indústria automóvel.

90. par=ext1350818-pol-92b-2: O massacre de 12 de Novembro trouxe à luz do dia o que tem sido a prática sistemática do exército de ocupação em Timor-Leste. 91. par=ext1258398-soc-97a-1: Quando vi luz mais à frente percebi que eram homens que participavam nas buscas e mandei deslocar alguns dos meus 
elementos para o local.

92. par=ext865416-pol-92a-1: Mandela disse ainda que a direcção do ANC decidirá na terça-feira, numa reunião convocada de emergência, as «opções» possíveis em relação à continuação do processo de negociações constitucionais, «à luz do que aconteceu».

93. par=ext1094900-nd-91b-1: No entanto, em nada ficará diminuído o espectáculo celeste, pois a noite oferece-nos agora -- durante todo o período em que a luz solar não alcança o nosso lugar -- a visão da parte do céu em que se concentram quase todas as estrelas de maior brilho, observáveis de qualquer ponto da Terra.

94. par=ext910526-nd-94b-2: Lingens fora, assim, e à luz da Convenção Europeia, ilegalmente condenado.

95. par=ext1192698-pol-96a-2: Em sinal de protesto, a oposição não compareceu e justificou a ausência numa conferência de imprensa conjunta, dada no salão nobre do Parlamento e que foi interrompida por um corte de luz, boicote seguido da "Grândola vila morena» cantada pelos deputados que ficaram às escuras 96. par=ext491337-com-98a-2: P. -- Os meus olhos são extremamente sensíveis à luz do computador.

97. par=ext550471-soc-97a-1: O advogado estivera desocupado toda a manhã, fazendo festas de sono nos olhos azuis, de costas para a luz da manhã.

98. par=ext1031882-soc-92b-1: A Igreja católica não tem o monopólio da verdade, mas tem a missão de ensinar a verdade de que se sabe depositária; não tem exclusivo das Escrituras, mas tem o dever de as interpretar com a luz do Espírito Santo.

99. par=ext374066-des-91b-1: Os livros, como aquele que o sr. Plácido Martins teve ultimamente a glória de dar à luz, são pois para o espírito português verdadeiros livros de renascença e de progresso.

100. par=ext805250-pol-98a-1: Há cerca de uma semana, Mário Carrascalão foi um dos principais animadores de uma reunião convocada por Abílio Osório Soares para discutir a situação de Timor-Leste à luz das mudanças em curso na Indonésia. 
Anexo 5 - Corpus das ocorrências do nome 'Luz' em CETEMPúblico.

\section{Corpus das ocorrências de CETEMPúblico}

Resultado da procura

30 de janeiro de 2021

Corpo: CETEMPúblico 1.7 v. 11.2

Pedido de uma concordância em contexto

Procura: nome "Luz"

10687 ocorrências.

A plataforma de CETEMPúblico apresentou uma amostra aleatória de 8000 das 10687 ocorrências encontradas.

Para esta pesquisa, escolheu-se uma amostra de 50 das ocorrências disponibilizadas pela plataforma descrita acima.

1. par=ext881571-clt-93b-2: Tiveram dois filhos, Luc e Luz.

2. par=ext479376-des-93b-1: Na passada segunda-feira, foi o ponto final nessa relação quando Pimenta Machado, presidente do Vitória de Guimarães, de passagem por Lisboa visitou Brito no Estádio da Luz e, inadvertidamente, deixou escapar que tinha almoçado com Alberto Silveira e José Gomes Machado, um dos mais empenhados dinamizadores do chamado «grupo da Valenciana», que pretende destituir o presidente da direcção do Benfica.

3. par=ext677842-soc-94a-1: São Vicente optou pela «Feira da Ladra», a velha Mouraria vai levar "Camareiras e marialvas», Campo de Ourique recorda os «Anos 20», o Bairro Alto presta homenagem a «Camões, vida e obra», Campolide apresenta os seus «Pátios e vilas», Carnide recorda os «400 anos da Senhora da Luz», e os Olivais vão mostrar a freguesia e as «Marés».

4. par=ext134169-des-92a-1: Discretamente, o médico do Benfica, Bernardo Vasconcelos, foi talvez o único a poder dar boas notícias ontem no estádio da Luz. 5. par=ext1344305-soc-96a-1: Este empreendimento, para além de agravar a poluição da água da Baía de Cascais que, destruirá todo o enquadramento da 
fortaleza da Luz e do forte da Cidadela, bem como, muito provavelmente, o Parque Gandarinha .

6. par=ext732379-soc-98a-2: A primeira fase prevê a ligação da Estrada Nacional n. .16 (nó da Catraia da Alegira) à Zona Industrial (intersecção com o acesso ao IP2) no nó do Bairro da Luz e corresponde a um investimento de cerca de um milhão e trezentos mil contos .par=ext732310-pol-98a-1: Embora os canais de televisão tivessem acompanhado a cerimónia durante toda a manhã, limitaramse a filmar o exterior do Alto de São João e da Igreja da Luz, por onde passou ontem de manhã e anteontem à noite, no velório, uma grande parte das figuras nacionais .

7. par=ext1107954-soc-96a-2: Isto porque o professor de Farmacologia Luz Rodrigues não foi mantido na Comissão, a que pertencia há 16 anos (era vogal).

8. par=ext1398719-soc-95b-2: Maria da Luz, uma das candidatas, vai lendo na Visão um texto sobre Carlos Candal e Paulo Portas enquanto anda.

9. par=ext653986-soc-95a-2: Os agentes mostravam-se particularmente eficientes no controlo do tráfego e dissuadiam alguns automobilistas, mais desesperados pelas longas filas -- demorava-se cerca de uma hora e meia a percorrer a curta distância entre a igreja da Luz e a Pontinha --, de invectivar os manifestantes.

10. par=ext908861-clt-94a-1: Sobre a primeira representação de «Senhora da Luz», na noite de sábado, 25, nas ruínas da Fábrica de Cerâmica de Carnide, abateu-se um vento forte e frio.

11. par=ext1545547-des-91b-1: Olhou primeiro as fotos do estádio da Luz espalhadas pela sala de reuniões do departamento de futebol.

12. par=ext861874-soc-95b-1: Acompanhados de autarcas e de técnicos da EDIA, os arquitectos contactaram com a população da aldeia, visitaram a igreja de Nossa Senhora da Luz, o cemitério e o castelo de Lousa, um monumento megalítico romano debruçado sobre o rio Guadiana, que será também inundado.

13. par=ext1410834-des-98b-1: A equipa treinou-se no campo número 3 do Estádio da Luz, dando início ao trabalho para o encontro de amanhã à noite 
(19h45) frente aos holandeses do PSV Eindhoven.

14. par=ext108288-clt-94b-2: Nas ruínas da Fábrica de Cerâmica de Carnide, nas noites de sábado, há desfile e representação de «Senhora da Luz".

15. par=ext1550867-des-91a-1: O treinador benfiquista optou pelos treinos à porta fechada, «para dar tranquilidade aos jogadores e para fazer bons treinos, sem coisas que distraiam», e terá recomendado aos seus homens que não se expandissem em declarações aos jornalistas -- que têm procurado o Estádio da Luz com uma frequência invulgar.

16. par=ext762107-soc-96b-1: As capelas mortuárias da Igreja da Luz, em Lisboa, vão ser transformadas, a partir de 6 de Setembro, em sala de exposição de objectos religiosos alusivos aos 400 anos do templo, cuja inauguração se comemora no dia 8 do próximo mês.

17. par=ext33406-soc-97a-1: As afirmações proferidas pela vereadora responsável pelo pelouro da Cultura da Câmara Municipal de Aveiro, Maria da Luz Nolasco, em declaração de voto justificativa da sua oposição a um pedido de viabilidade de construção de um imóvel no centro da cidade, numa recente reunião do executivo camarário, dominaram a reunião de anteontem da Assembleia Municipal (AM) .

18. par=ext361660-des-92a-1: O ponto de encontro foi a praia da Luz, na foz do Douro, poiso tradicional dos aficionados portuenses.

19. par=ext587002-des-97a-1: Não foi bem às oito da manhã mas, poucos minutos antes do meio-dia, Wilson voltou a pisar o relvado número dois do estádio da Luz para uma sessão de trabalho a «meio gás».

20. par=ext663754-des-93a-2: «Hoje o que interessa é ver o jogador, amanhã então será o encontro com o FC Porto», diziam os muitos associados do Benfica que na tarde de ontem invadiram o Estádio da Luz.

21. par=ext423917-soc-95a-2: Maria da Luz Rosinha, presidente da concelhia socialista de Vila Franca de Xira, afirma que o urbanismo «é um dos pontos frágeis e controversos da gestão municipal» e sugere que «o vereador Carlos Silva alteraria alguns dos rumos que têm sido seguidos ao nível da política urbanística da Câmara» . 
22. par=ext1211333-nd-94b-2: -- O Benfica recebe, no estádio da Luz, a equipa do Steaua de Bucareste, em jogo da $3^{\underline{a}}$ jornada do grupo $\mathrm{C}$ da Liga dos Campeões Europeus.

23. par=ext1205913-soc-95b-1: Maria da Luz Rosinha, presidente da concelhia do PS, questionou a Câmara sobre esta matéria, considerando que o novo hospital deverá servir concelhos de Alenquer, Azambuja, Arruda e Benavente e que o PDM previa a construção deste equipamento a norte da sede de concelho.

24. par=ext256004-nd-91b-2: A comitiva helénica (que ontem realizou ainda um treino ao fim da tarde no campo do Sacavenense e amanhã à noite tem uma sessão de trabalho marcada para o Estádio da Luz) integra 18 jogadores -Guarda-redes: Sarganis (do Athinaikos) e T. Papadopoulos (Panionios) ; defesas: Apostolakis (Panathinaikos), Marinakis (OFI), Karageorgiou (Panathinaikos), Mitsibonas (PAOK) , Kalintzakis (Panathinaikos) e lorgos Papadopoulos (Iraklis) ; médios: Tsiantakis (Olympiakos) , Karapialis (Olympiakos), Papaioannou (AEK) e Tsalouhidis (Olympiakos) ; avançados: Saravakos e Athanassiadis (Panathinaikos) , Dimitriadis (AEK) e Borbokis (PAOK) .

25. par=ext798281-soc-92a-1: E, após dois anos de mandato, o Secretariado da central dos pequeninos quer substituir o socialista Chagas pela comunista Maria da Luz.

26. par=ext1095997-des-97a-1: A movimentação no estádio da Luz foi bastante diferente do que tem sido hábito nos últimos tempos.

27. par=ext563968-pol-93a-1: Em termos de apoios, Onésimo Silveira revelou que os primeiros passos serão dados com a contribuição voluntária dos cidadãos que aderirem ao projecto, mas que conta, à partida, com a ajuda de cabo-verdianos no exterior, tendo, a propósito, desmentido que o antigo ministro dos Negócios Estrangeiros, Silvino da Luz, faça parte da ED, conforme aventado pelo «Expresso».

28. par=ext141157-clt-92a-2: Anunciavam-se números astronómicos: palcos de tal maneira largos que quase chegavam ao estádio da Luz, não sei quantos milhões de «watts", para a iluminação e o som.

29. par=ext1287419-soc-96a-2: «Lisboa Cidade Luz» de Herlander Zambujo 
patente na galeria de arte Página 75, no primeiro andar do Centro Comercial da Portela.

30. par=ext1275033-des-92a-2: Na Grande Lisboa, destacam-se a referida Associação dos Lisbonenses Amadores de Bilhar, na rua Gonçalves Crespo, o Clube Bilharista da Amadora, na rua Sete de Junho, o Ateneu Comercial de Lisboa, na rua das Portas de Santo Antão, Grémio Lisbonense, na rua dos Sapateiros, e as salas do Benfica, uma na sede do clube, na rua Jardim do Regedor, e outra no Estádio da Luz.

31. par=ext781199-clt-92b-2: Simonetta Luz Afonso, igualmente administradora de Lisboa 94, não participou entretanto na reunião de anteontem por se encontrar ausente do país.

32. par=ext540782-soc-95a-1: Compostos de mercúrio, ácido asséptico, reagentes vários, álcool propílico e outros produtos laboratoriais perigosos para a saúde foram despejados a céu aberto na Rua João Hogan, por trás do Estádio da Luz, em Lisboa, perto de um núcleo de barracas, não longe de prédios de habitação e num local onde frequentemente brincam crianças.

33. par=ext792890-soc-98a-1: Neste capítulo, Maria da Luz destacou as obras em curso na entrada norte de Vila Franca, a recuperação do antigo Café Central e o arranjo da zona ribeirinha de Alhandra.

34. par=ext1431036-des-95a-1: Pela primeira vez nas últimas épocas, os finalistas do «Nacional» de basquetebol da I Divisão, Benfica e FC Porto, têm que disputar o quinto encontro, esta noite (21h), no Pavilhão da Luz, em Lisboa, para aí decidirem quem fica com o título de campeão, a culminar uma temporada que ficará conhecida como a do pré-profissionalismo .

35. par=ext1171719-des-92a-1: Terminou ontem na Praia da Luz, no Porto, a segunda etapa do Circuito O'Neil-Pisang Ambon Surf 92, tendo Rodrigo Herédia acabado por vencer a finalíssima anteontem disputada.

36. par=ext1498779-des-91b-1: Recorde-se que a Federação Portuguesa de Futebol apresentou as candidaturas dos Estádios das Antas para a Taça dos Campeões e do Estádio da Luz para a Taça das Taças.

37. par=ext903185-des-96a-1: Bancadas da Luz -- Foram 30 mil espectadores. 
38. par=ext1376156-opi-98b-2: E, mais uma vez, não haveria que desperdiçar as potencialidades não institucionais do Espaço Lusófono, pedindo a assessoria de homens com profundo conhecimento do terreno e da sua componente humana como os generais Ramalho Eanes, Pedro Pires ou Silvino da Luz.39. par=ext268125-clt-93b-1: A direcção da Arqueonáutica -- Centro de Estudos, decidiu ontem denunciar ao Instituto Português do Património Arquitectónico e Arqueológico (IPPAR) a descoberta, não declarada às autoridades, de um cepo de âncora romano, recuperado em Janeiro de 1992 a cerca de $\mathbf{3 0 0}$ metros da Praia da Luz, no Algarve.

40. par=ext1226641-nd-91b-1: Da parte portuguesa intervieram José Ribeiro da Fonte (música antiga e contemporânea), Miguel Lobo Antunes (cinema e animação) , Eduardo Prado Coelho (literatura e teatro), Gil Mendes (dança) e Simoneta Luz Afonso (arte antiga, moderna e contemporânea) .

41. par=ext642426-soc-91b-2: A sua falta foi sentida, pela primeira vez, num jantar que combinara com um grupo de amigos, na Feira da Luz, em Lisboa. 42. par=ext1350781-soc-96a-1: E ainda o Farol da Nossa Senhora da Luz, na Foz do Douro.

43. par=ext530311-des-93a-1: Os esgueirenses, com as duas derrotas com que saíram do pavilhão da Luz, terão de bater os «encarnados» por duas vezes, para ainda terem hipóteses.

44. par=ext1390983-soc-94b-2: Na Fortaleza da Nossa Senhora da Luz, Cascais, encontra a exposição de pintura «Tordesilhas / 94 ", dos pintores Rui Azevedo e Carlos Torres.

45. par=ext931678-des-93b-2: Foi uma tremenda desilusão para a multidão que quase enchia as bancadas da Luz, tanto mais que a equipa ficou a dever a si própria um resultado mais dilatado.

46. par=ext14309-des-91b-2: AAS 18.50, Mário Soares condecoraria João Havelange numa cerimónia muito breveÀ saída do Estádio da Luz, ainda as felicitações não tinham acabado, essencialmente dirigidas a João Rodrigues, presidente da FPF («feliz e realizado pelo sucesso desportivo e da organização»), Ribeiro de Magalhães e Azevedo Félix, também dirigentes da Federação . 
47. par=ext730439-soc-96a-1: Trinta mil contos é quanto custará, segundo a Câmara, a reconstrução de pavimentos e desobstrução de esgotos pluviais na Estrada Municipal 576-2, na Serra da Luz, Pontinha.

48. $p a r=e x t 368955-d e s-91 b-1:$ O Nacional da I Divisão prossegue com quatro confrontos agendados para hoje e um Benfica-Sporting a disputar amanhã, no pavilhão da Luz.

49. par=ext970087-soc-94b-2: Às $21 \mathrm{~h} 30$, no recinto da Feira da Luz, em Montemor-O- Novo.

50. par=ext85773-soc-97b-1: A nova Aldeia da Luz, cujo início da construção dos edifícios de habitação está previsto para meados de 1998, ficará pronta a habitar antes do final do ano 2000, altura em que serão encerradas as comportas da barragem do Alqueva, anunciou o Ministério do Equipamento.

Anexo 6 - Corpus das ocorrências nas letras de samba-enredo.

Resultado da investigação

28 de dezembro de 2020

Pesquisa do uso do item lexical 'luz' nas letras de samba-enredo.

Corpo: https://www.letras.mus.br/beija-flor-rj/

Concordância

Procura: "luz".

Apresenta-se uma amostra de 17 letra de samba enredo nas quais é usada a palavra 'luz' como parte das temáticas da Escola de Samba Beija-Flor de Nilópolis. Tema da letra de samba-enredo da Escola de Estrofe onde o item lexical 'luz' Samba Beija-Flor de Nilópolis. é usado como parte da letra de samba-enredo.

1. Samba Enredo 1987 - As Mágicas Luzes Ao descerrar a cortina

Da Ribalta. $\quad O$ palco se ilumina 


\begin{tabular}{|c|c|}
\hline & $\begin{array}{l}\text { Tudo é brilho, luz e cor (luz e } \\
\text { cor) }\end{array}$ \\
\hline $\begin{array}{l}\text { 2. Samba Enredo } 1990 \text { - Todo Mundo Nasceu } \\
\text { Nu. }\end{array}$ & $\begin{array}{l}\text { A luz resplandeceu no caos } \\
\text { Anunciando um novo dia } \\
\text { Haja terra, água, fogo e ar } \\
\text { Imensas florestas, terríveis } \\
\text { animais }\end{array}$ \\
\hline $\begin{array}{l}\text { 3. Samba Enredo } 1992 \text { - Há um ponto de luz } \\
\text { na imensidão. }\end{array}$ & $\begin{array}{l}\text { Um ponto de luz surgiu, oi! } \\
\text { Na magia desta invenção } \\
\text { Descortinando o infinito }\end{array}$ \\
\hline $\begin{array}{l}\text { 4. Samba Enredo } 1993 \text { - Uni, Duni, Tê, a } \\
\text { Beija-flor Escolheu, É Você }\end{array}$ & $\begin{array}{l}\text { Gira, meu mundo-pião } \\
\text { De listras brancas e azuis } \\
\text { E vai bordando no chão } \\
\text { Um arco-íris de luz... }\end{array}$ \\
\hline $\begin{array}{l}\text { 5. Samba Enredo } 1995 \text { - Bidu Sayão e o } \\
\text { Canto de Cristal. }\end{array}$ & $\begin{array}{l}\text { Grande guerreira que } \\
\text { conquistou } \\
\text { Seu lugar ao Sol } \\
\text { É festa, é luz, é cor, é poesia } \\
\text { É diva internacional }\end{array}$ \\
\hline $\begin{array}{l}\text { 6. Samba Enredo } 2000 \text { - Brasil - Um Coração } \\
\text { que Pulsa Forte. Pátria de Todos ou Terra de } \\
\text { Ninguém. }\end{array}$ & $\begin{array}{l}\text { Luz celestial que ilumina } \\
\text { Astros abrem a porta divina } \\
\text { Guiando a navegação } \\
\text { Descobrindo esta nova nação } \\
\text { - - - - - } \\
\text { Meu Rio, eu sonhei } \\
\text { Que o Senhor havia nos dado } \\
\text { a mão } \\
\text { Que havia ordem, progresso e } \\
\text { perdão } \\
\text { E um ser de luz a iluminar }\end{array}$ \\
\hline
\end{tabular}

RC: 106976

Disponível em: https://www.nucleodoconhecimento.com.br/letras/linguistica-cognitiva 
7. Samba Enredo 2001 - A Saga de Agotime, Maria Mineira Naê.

8. Samba Enredo 2003 - O povo conta a sua história: "saco vazio não pára em pé" - a mão que faz a guerra faz a paz.

9. Samba Enredo 2004 - Manôa - Manaus Amazônia - Terra Santa... Que Alimenta O Corpo, Equilibra A Alma E Transmite A Paz.

10. Samba Enredo 2008 - Macapaba: equinócio solar, viagens fantásticas do meio do mundo.

11. Samba Enredo 2010 - Brilhante ao sol do novo mundo, Brasília: do sonho à realidade, a capital da esperança.

12. Samba Enredo 2011 - Roberto Carlos: a Simplicidade do Rei.
Maria Mineira Naê

Agotime no clã de Daomé e na luz dos seus Voduns Existia um ritual de fé

Luz, divina luz que me conduz Clareia meu clarear, clareia Nas veredas da verdade, cadê a felicidade?

Aportei, num santuário de ambição

Se Deus me deu vou preservar Meus filhos vão se orgulhar A Amazônia é Brasil, é luz do criador

Avante com a tribo Beija-Flor

No manto azul da fantasia

Me faz mais forte, extremo norte

A luz solar ilumina meu interior Vou viajar na linha do Equador Sou candango, calango e Beija-Flor!

Traçando o destino ainda criança

A luz da alvorada anuncia!

Brasília capital da esperança Momentos que não esqueci Eu cheio de fantasias na luz do Rei menino

Lá no seu Cachoeiro 
13. Samba Enredo 2012 - São Luís? O Poema Encantado do Maranhão.
Na casa nagô a luz de Xangô

Axé

Mina Jêje um ritual de fé

Chegou de Daomé, chegou de

Abeokutá

Toda magia do vodun e do orixá

14. Samba Enredo 2016 - Mineirinho Genial! Nova Lima, Cidade Natal. Marquês de Sapucaí, O Poeta Imortal.

15. Samba Enredo 2017 - A Virgem Dos Lábios de Mel - Iracema.

16. Samba Enredo 2018 - Monstro É Aquele Que Não Sabe Amar (Os Filhos Abandonados da Pátria Que Os Pariu).
Teu chão floresce a nobreza

pro samba passar

Um templo sagrado a luz do luar

Apoteose de todo sambista Artista! herdeiro verdadeiro de Ciata

Que hoje te abraça aos pés da praça

Em mais um carnaval

Ó linda Iracema morreu de saudade

Mulher brasileira de tanta coragem

Um raio de sol a luz do meu dia

lluminada nessa minha fantasia

Retalhos do meu próprio Criador Julgado pela força da ambição Sigo carregando a minha cruz À procura de uma luz, a salvação! 
17. Samba Enredo 2019 - Quem Não Viu, Vai Ver... As Fábulas do Beija-Flor.
Oh, deusa

Tem festa no meu coração

Desfilo toda gratidão

Razão do meu cantar, a luz do meu viver

O que seria de mim sem você?

\section{APÊNDICE - REFERÊNCIA NOTA DE RODAPÉ}

2. https://www.conjugacao.com.br/verbo-luzir/

3. Segundo Scorsolini-Comin, F., Pacífico, S., \& Romão, L. (2011), tudo é uma trama, um jogo, uma produção de sentidos que não se finda com a passagem da escola pela avenida, tampouco com a escolha de um significante e não de outro. Com a finalização do desfile, não se instaura a resolução dos segredos e das expectativas criadas em torno do enredo "É segredo!", mas continua o movimento de produção de sentidos, solicitando ao espectador um exercício no sentido de compreender as polissemias em desfile e em discursos.

4. Houaiss (2009), Aurélio (2010) e Michaelis (2015).

Enviado: Janeiro, 2021.

Aprovado: Fevereiro, 2022.

RC: 106976

Disponível em: https://www.nucleodoconhecimento.com.br/letras/linguistica-cognitiva 